\title{
Oversigt over befolkningsforholdene i Sønderjylland i middelalderen. ${ }^{*}$ )
}

\author{
Af Johan Hvidtfeldt.
}

Der har været fremsat talrige teorier om den befolkning, der boede i Sønderjylland og Danmark i stenalderen og broncealderen, men teoriernes mangfoldighed viser tydeligt, hvor usikker vor viden $i$ virkeligheden er. Man tør dog regne med, at der ingen forskel har været mellem befolkningen i Sønderjylland og den øvrige del af den jyske halvø ${ }^{1}$ ), idet den kultur, som de arkæologiske fund bærer vidne om, er den samme nord og syd for Kongeaaen. I aarhundrederne efter Kristi fødsel begynder de historiske beretninger at kaste enkelte strejflys hen over landsdelen, men deres efterretninger er saa usikre og saa omdiskutable, at det ikke er muligt at danne sig et paalideligt billede af forholdene. Litteraturen om dette sporgsmaal er meget omfattende og meningerne stærkt delte. Et af de mest brændende problemer $\mathrm{i}$ denne tids historie er anglerne, hvis bopladser snart er blevet henlagt til Angel, snart til hele S'ønderjylland og snart til Thüringen eller andre steder i Tyskland, mens enkelte har ment, at navnet er opstaaet i England efter indvandringen. Ogsaa i de seneste aartier er spørgsmaalet gentagne gange taget op til drøftelse ${ }^{2}$ ), og adskillige forskere er nu tilbøjelige til at mene, at de angler, som $i$ det 5. aarhundrede

*) Dansk Kultursamfund og Den Hjelmstierne-Rosencroneske Stiftelse bringer jeg en hjertelig tak for underst $\varnothing$ ttelse til mine studier over sønderjydske befolkningsforhold.

1) Aarbøger for nordisk Oldkyndighed 1913, 321 og 1914, $274 \mathrm{ff}$. (Sophus Møller). Sønderjyllands Historie I, $135 \mathrm{f}$.

2) En oversigt over kilderne og den ældre litteratur hos Erdmann: Uber die Heimat und den Namender Angein (1890) og Zeitschrift LXX/XXI (19:43) 1 ff. Paa dansk side er spørgsmaalet $i$ nyere tid især behandlet af $\mathrm{Gudmund} S \mathrm{ch}$ u $\mathrm{t}$ te, bl. a. i Sønderjydske Aarbøger 1900, Ptolemy's Maps of Northern Europe (1917) og Sydslesvig, Angel (1945), og af $\mathrm{Herman} \mathrm{M} \varnothing 11$ e r i Anzeiger für deutsches Altertum $u$. deutsche Litteratur XXII (1896). 
invaderede England, virkelig er kommet fra Angel $^{3}$ ), som skulde have faaet sit navn efter et gammelt navn paa Slien, udledt af adjektivet angr (snæver) eller et tilsvarende substantiv ${ }^{4}$ ). Et stærkt - om ikke afgørende - vidnesbyrd om, at anglernes hjemstavn virkelig skal søges i Sønderjylland, giver det arkæologiske materiale, som viser, at befolkningen i Angel tog stærkt til efter det 3. aarhundrede, medens en stærk aftagen af fundene i det 5. aarhundrede tyder paa en udvandring. Af særlig interesse er det, at der i de særligt angelske omraader af England er fundet oldsager, der stammer fra omtrent samme tid og typologisk synes at have samme særpræg som de angelske eller i hvert fald er en videreførelse af disse typer ${ }^{5}$ ). Selvom det maa pointeres, at slutningerne paa grundlag af det arkæologiske materiale, der foreligger for øjeblikket, ikke er alt for sikre, tør man dog sige, at meget tyder paa, at anglerne har boet i det sydlige Sønderjylland, og at de, da de omkring midten af det 5. aarhundrede udvandrede til England, efterlod et nogenlunde mennesketomt land.

Men anglerspørgsmaalet frembyder ogsaa andre problemer af interesse, som maa berøres, naar man vil forstaa de ældste befolkningsforhold i Sønderjylland. Selvom man mener, at det maa anses for sandsynligt, at anglerne har boet i Østslesvig, er dermed ikke sagt, at det angelske omraade kun har omfattet selve landskabet Angel. Der findes ikke direkte udtalelser om udstrækningen af den angelske bosættelse, og der er heller ikke gennem sproghistoriske undersøgelser nogen mulighed for at faa et holdepunkt herfor. Derimod synes det arkæologiske materiale at sandsynliggøre, at selvom anglernes hovedsæde maa have været i Angel, har den angelske kulturkreds dog ogsaa

s) Et andet synspunkt er dog bl. a. hævdet af Otto Scheel i Die Heimat der Angeler (Schriften der wissenschaftlichen Akademie des NSD-Docentenbundes der Christian Albrechts-Universität Kiel IX, 1939), jvnfr. ogsaa samme: Die Vikinger. Aufbruch des Nordens (1938), $42 \mathrm{ff}$.

4) Classica et mediaevalis IV (1941), $62 \mathrm{ff}$ ( $\mathrm{Kr}$. Hald).

s) Zeitschrift LXX/XXI (1943), 46 ff. (Jankuhn). 
omfattet Svans, mens den har været adskilt fra sydligere kulturomraader ved ubeboede strækninger, hvor intet arkæologisk fund forekommer. Ogsaa fundene nordfor Angel i den sydlige del af Sundeved og egnen nord og nordvest for Flensborg synes at vise sammenhæng med den angelske kulturkreds, mens fundene længere mod nord tegner omridsene af en kultur med sit egenartede fremtoningspræg. Tyske arkæologer har benævnt den efter landsbyen Over-Jersdal ${ }^{\circ}$ ). Man har fremsat den antagelse, at befæstningsanlæg ved Lovtrup og Uge i nærheden af Tinglev (Olmersdiget) skulde være vejspærringer paa grænsen mellem de to kulturkredse ${ }^{7}$ ). Paa forhaand synes teorien meget sandsynlig, men dateringen af befæstningsanlæggene er dog vist $\mathrm{i}$ øjeblikket for usikre til, at man kan drage sikre slutninger med hensyn til grænsen mellem angler og jyder.

Men naar det maa anses for sandsynligt, at anglerne har boet mellem sakserne mod syd og jyderne mod nord, bliver spørgsmaalet, hvilke af disse anglerne har staaet nærmest med hensyn til kultur og sprog. Undersøgelser foretaget paa grundlag af ordforraadet i sprogtekster, der stammer fra det angelske kolonisationsomraade i England, har vist, at det angelske sprog i det store og hele stod nærmere ved nordisk end ved saksisk, som derimod havde nærmere tilknytning til oldsaksisk og frisisk. Forskellene er dog ikke særlig store og tyder ikke paa, at de to folk $i$ deres fastlandstilværelse har levet altfor langt fra hinanden ${ }^{8}$ ). Det arkæologiske fundmateriale viser en ret stærk forbindelse med kulturomraadet syd for Ejderen'), men ogsaa tilknytning til Over-Jersdal-kredsen og til Fyn kan paavises ${ }^{10}$ ).

6) Zeitschrift LXX/XXI, 39 (Jankuhn), Carl Schuchardt: Die Urnenfriedhöfe in Niedersachsen (1921), 55 f, Fritz Tischler: Fuhlsbüttel, ein Beitrag zur Sachsenfrage (1937), 67.

7) Sønderjyllands Historie I, 153 f. (la Cour).

8) Richard Jordan: Eigentümlichkeiten des anglischen Wortschatzes (Anglitische Forschungen XVII) 1906, $122 \mathrm{f}$. En lignende opfattelse er ogsaa tidligere hævdet af den danske forsker Herman Møller.

9) Schuchardt: anf. sted 56.

10) Zeitschrift LXX/XXI, 39 (Jankuhn). 
Anglerne maa altsaa kulturelt have indtaget en mellemstilling mellem sakser og jyder, en stilling, der svarer til deres geografiske placering, og deres sprog kan hverken henregnes til saksisk eller jysk.

Som nævnt tyder de arkæologiske fund paa, at Angel efter udvandringen maa have været forholdsvis folketomt, og at det var sterstedelen af befolkningen, som drog med paa den lange rejse, som førte til det nye hjem mod vest. Bedas udtalelser $\mathbf{i}$ hans Historia ecclesiastica gentis Anglorum om, at Angel i hans tid har ligget ode hen (de illa patria quae hodie manere desertus inter provincias Jutarum et Saxonum perhibetur), bekræfter saaledes det arkæologiske materiales vidnesbyrd. Naar Angel $\mathbf{i}$ historisk tid har et saa rent dansk sprog, som tilfældet er, viser det ogsaa, at omraadet maa have været helt eller næsten helt rømmet af dets tidligere beboere. Var en større del af disse bleven tilbage, vilde de kommende aarhundreders angelboere være blevet et blandingsfolk, og da angelsk kultur og sprog havde sit særpræg, der afveg en del fra de rent nordiske naboers, vilde man paa kulturens forskellige omraader have været i stand til at paavise et angelsk indslag, $f$. eks. i stednavne og sprog. Men dette er ikke tilfældet. Angel har i historisk tid samme kulturpræg som den nondlige del af Sønderjylland. Naar det blev jyderne, der kom til at udfylde det befolkningsmæssige tomrum, der opstod ved anglernes bortvandring, mens sakserne ikke udnyttede denne mulighed for expansion mod nord, skyldes det vel i første række, at udvandringen til England havde svækket disses kolonisationsevne i hjemlandet, men ogsaa, at de var adskilt fra Angel ved store øde strækninger.

Men hvor langt naaede de jyske kolonisatorer mod syd, hvor har det danske folks sydligste grænse gaaet? Der findes ingen direkte udtalelser om spørgsmaalet, og i øjeblikket er der kun eet middel til at besvare det: stednavnene. Baade fra dansk og tysk side ${ }^{11}$ ) har man paa dette grundlag søgt at angive grænsen

11) Især P. Lauridsen i Sdj. Aarb. 1893 og August Sach i Das Herzogthum Schleswig in seiner ethnografischen $u$. nationalen Entwickelung I-III (1896-1907). 
for den sydligste sammenhængende bosættelse. Efter at det store sydslesvigske stednavnemateriale nu er blevet samlet ved danske forskeres arbejde, er det muligt at trække linien op med meget stor sikkerhed, idet man i brugen af stednavnene altid har været meget konservativ. Danske navne kan leve videre i aarhundreder, efter at befolkningen er blevet tysk, og da stednavneforskningen har temmelig sikre midler til at udskille de ældste lag af navnestoffet, kan man ved at undersøge grænseomraadets stednavne sogn for sogn klarlægge, hvor langt ned den ældre danske bebyggelse er gaaet. Mod vest, hvor dansk, nedertysk og frisisk stødte sammen, var forholdene særligt indviklede. Grænsen her gik syd for Rödemis, Mildsted.og Rantrum og antagelig helt ned til Svavsted, som baade kan være dansk og tysk, men dog snarest er dansk. Derefter gik den mod nordøst lidt syd for Hollingsted, hvorefter den nogenlunde fulgte Arns herreds sydlige grænse og Dannevirke. Omtrent ved Jagel bøjede den atter mod syd til Boklund og herfra mod øst til syd for Hummelfeld for derefter at slaa en bue mod nord. Hele Svans hører afgjort til det danske omraade. Bortset fra Svans, der først forholdsvis sent kan paavises at have faaet herredsnavn, falder sydgrænsen for de danske stednavne og herredsinddelingen omtrent sammen.

Egnen sydfor det danske kulturomraade har uden tvivl igennem mange aarhundreder været relativ folketom. Store ubeboede skovstrækninger adskilte danerne fra deres naboer mod syd. Endnu ca. 1190 skal Esbern Snare have omtalt egnene mellem Danmark, Holsten og Vagrien som en stor ødemark (uastam solitudinem, que coniunget Schlauiam, Holsatiam et Daciam) ${ }^{12}$ ). Der kan ikke være tvivl om, at paa dette tidspunkt har spredte danske kolonisatorer overskredet grænsen for den samlede danske bebyggelse og er naaet længere mod syd helt ned i Dänisch-Wohld, hvor navnet Gettorf (sammensat af mandsnavnet Get og torp) er en uomtvistelig dansk bosættelse. Længere mod vest møder vi Haby og Norby, som ogsaa maa

12) M. Cl. Gertz: Scriptores Minores II, 466 f. 
være af nordisk oprindelse. En del andre stednavne, som man har villet tolke som danske, maa derimod efter de nyeste undersøgelser være tyske, f. eks. Aschau, Owschlag og Nübbel ${ }^{18}$ ). Særlig omfangsrige eller talrige har de danske koloniomraader dog næppe været. Vi kender nu kun faa, og selvom nogle kan være forsvundet uden at efterlade sig spor, tyder forholdene $\mathrm{i}$ det 13. aarhundrede og senere dog ikke i retning af stærke danske befolkningselementer hernede.

Ogsaa sydfra har enkelte saksiske kolonisatorer begyndt at tage den jomfruelige jord i de store ødemarker under plov. Hvornaar denne kolonisation er begyndt, kan ikke siges, men det maa i hvert fald være sket noget for $1200^{14}$ ), thi nogle af de holstenske navneformer i den sydlige del af omraadet bærer et betydeligt ældre præg. Det gælder f. eks. Duvenstedt, som har et personnavn som forled og -stede som efterled, en navnetype, der ikke forekommer i det tidligere vendiske Østholsten, hvor kolonisationen begyndte $i$ første halvdel af det 12 . aarhundrede, og som derfor maa være ældre ${ }^{15}$ ). En nøjere undersøgelse af en udtalelse $i$ kong Valdemars jordebog fra ca. 1231 giver ogsaa visse kronologiske holdepunkter, det hedder her „Fræzlet cum Ykærnæburgh c mr. puri. Dominus rex habet inter Slae et Eydær CCCC houae et xx. In Swansø xxi aratra et dim. et preter hoc multas siluas. $\mathrm{S}$ w a $\mathrm{n} . \mathrm{x} \mathrm{mr}$. argenti. Kamp $\mathrm{x} \mathrm{mr}$.

13) Sønderjydske Aarbøger 1944, 16 (Bjerrum).

14) P. Lauridsen mener, at holstenske kolonisatorers overgang over Ejderen først kan have fundet sted efter midten af det 12. aarhundrede, og at det forst er efter 1200, at den tyske bebyggelse rigtig tager fat (Sønderjydske Aarbøger 1893, 253 ff.). Sach slutter sig nærmest til Lauridsens opfattelse (anf $\varnothing$ rte sted II, 20). Begge er af den opfattelse, at de danske kongers holstenske politik $i$ begyndelsen af det 13. aarhundrede, hvorved Holsten for en tid kom under dansk overhøjhed, har været fremmende for den tyske indvandring, eller som la Cour udtrykker det: »Man kunne fristes til at sige, at det eneste blivende Resultat, som Erobringen af Holsten gav os, var det sydlige Slesvigs nationale Tab« (Sønderjyllands Historie I, 983). Denne opfattelse er dog næppe holdbar og er sikkert i for høj grad præget af moderne forestillinger om statsgrænsernes betydning $i$ befolkningsmæssig henseende.

15) Sønderjydske Aarbфger 1944, 17 f. jvnfr. 6. 
argenti". Senere under omtalen af kongelevet opføres Jarnwith og Kamp ${ }^{16}$ ).

Oprindelig laa hele omraadet ned mod Ejderen uopdyrket hen. Det var i retslig henseende en slags alminding, som efter de gældende regler tilhørte kongen, og det var selvfølgeligt, at han hævdede denne ret. Derfor kan der i jordebogen opføres 420 gaarde som tilhørende kongen ${ }^{17}$ ). Men var det saa det samlede antal ejendomme sydfor Sli, var gaardene spredt over hele egnen mellem Sli og Ejder, eller laa de kun i en del af omraadet? Naar der midt i jordebogens latinske tekst pludselig bruges et tysk udtryk houae (jvnfr. moderne tysk Höfe) i stedet for mansus er der kun een forklaring mulig. Disse 420 gaarde maa have været bygget og beboet af tyske kolonister, ikke af danske. Men da stednavnene viser, at Svans og omraadet lige syd for Dannevirke paa denne tid var dansk beboelsesomraade, maa man formode, at ingen af de 420 gaarde skal søges her, men at de alle, eller saa at sige alle, har ligget syd herfor, især i det saakaldte Jernved (Isarnho), det senere Dänischwohld, og i Kamp, der maa være den sydligste del af Slesvig ${ }^{18}$ ).

Men er denne antagelse rigtig, maa forholdene $\mathrm{i}$ den sydligste del af Slesvig i første halvdel af det 13. aarhundrede ses under en helt ny synsvinkel. De 420 gaarde maa have udgjort en ikke ringe bebyggelse, antagelig svarende til 50-70 landsbyer. Skulde denne omfattende kolonisation næsten udelukkende være opstaaet i aartierne efter 1200 , maatte opdyrkningsbevægelsen have haft en fuldstændig eksplosiv karakter og være foregaaet $i$ et tempo, som synes meget lidet sandsynligt, ikke mindst naar man tager i betragtning, at der er tale om jord, som ikke før har været under plov. Kun ved at forudsætte, at kolonisationen har strakt sig over et betydeligt længere tids-

16) Kong Valdemars Jordebog ed. Sv. Aakjær 10.

17) Paul Johs. Jørgensen: Dansk Retshistorie (1940), 185 ff.

18) Sach: anførte sted I, 41 ff., III, 21 ff., Kong Valdemars Jordebog 92, Chr. L. E. Stemann: Geschichte der öffentlichen und Privatrechts des Herzogthums Schleswig I, 18 ff., 162 ff., S $\varnothing$ nderjyllands Historie I, $483 \mathrm{ff}$. 
rum og maaske gaar helt tilbage til 1100 , kan man give en rimelig forklaring paa den omfattende bebyggelse. Om enkelthederne i forløbet af dette første store tyske fremstød mod nord kan der intet siges nu, de vil først kunne udredes, naar der foreligger en udførlig redegørelse for hele stednavnestoffet fra den sydligste del af Slesvig, saa man kan udskille de ældre og yngre dele af bebyggelsen og muligvis nærmere datere disse. Først da vil man ogsaa kunne sige, om den tyske bebyggelse omkring 1231 paa hele linien mellem Østersøen og Vesterhavet er naaet op til de sydligste danske forposter, eventuelt helt op til den sammenhængende danske bebyggelse. Saa længe vor viden er saa knap som i øjeblikket, kan man ikke helt udelukke muligheden af, at der, i hvert fald omkring 1190, har været et større eller mindre tomrum mellem de to folk, som retfærdiggør Esbern Snares udtalelse.

Naar man vil forstaa de sønderjyske befolkningsforhold ved oldtidens slutning, er der endnu to problemer, som maa belyses: Friserne og den svenske bebyggelse i Sydslesvig. De arkæologiske undersøgelser har vist, at vesterhavsøerne har været befolket i ældre tid, og man har $i$ almindelighed ment, at fundene tydede paa, at det var en nordisk befolkning, der levede her ${ }^{19}$ ). Men da stednavnestoffet paa øerne overhovedet ikke bærer vidnesbyrd om nogen nordisk bosættelse, bortset fra nordenden af Sild, har sproghistorikeren Peter Jørgensen, der er den forsker, der sidst har beskæftiget sig med problemet, hævdet, at geestøerne Sild og Før-Amrum samt de højere dele af Ejdersted og omraadet ved Ejdermundingen fra den ældste tid har været beboet af folk, der talte et nordvestgermansk sprog og hørte til en række germanske stammer, der boede langs Vesterhavets kyst og ned til Rhinmundingen.

Nogle aarhundreder efter Kristi fødsel ophørte næsten al beboelse i Ejdersted, mens den blev fortsat paa øerne. Senere

19) Sønderjyllands Historie I, 318 ff, Herbert Jankuhn: Die Wehranlagen der Wikingerzeit zwischen Schlei und Trene (1937). 55. 
begyndte der paa Sønderjyllands vestkyst en omfattende marskdannelse, som efterhaanden lokkede en stor del kolonisatorer til. Danskerne besatte dele af Viding og Bøking herreder, Ditmarskerne enkelte steder i Ejdersted, men langt de fleste af kolonisterne var frisere, indvandret sydfra, ikke fra me. Deres sprog var nær beslægtet med de oprindelige beboeres, selvom der ogsaa var forskelligheder. Det er umuligt med sikkerhed at datere denne indvandring, men det er sandsynligt, at den er sket i 2. halvdel af det 8. aarhundrede ${ }^{20}$ ).

Friserne i marsken og paa øerne indtog en vis administrativ og retslig særstilling indenfor det danske rige, de var „frisere under frisisk lov“ („Frysones de lega Frysonica“), og det af dem beboede omraade kaldes for Utland, et udtryk der forekommer saa tidligt som 1187. Fra marsken naaede friserne ind paa geesten, der fra gammel tid havde været beboet af danskerne. Disse frisere kaldtes i modsæetning til deres stammefrænder længere mod vest for "frisere under dansk lov" (Frysones de lege Danica), som det hed i den ældre slesvigske stadsret. Foruden at være et vidnesbyrd om de to gruppers forskellige retslige stilling, viser udtrykket, at friserne her „var fremmede indvandrede $\mathrm{i}$ alt bestaaende danske retskredse ${ }^{\text {(21 }}$ ). Indvandringen til geesten, der altsaa ikke skyldtes en ny sydfrisisk indvandringsbølge, men kun var en udvidelse af det allerede bestaaende frisiske befolkningsomraade, er formodentlig først sket efter 1100 og har sikkert strakt sig over en forholdsvis lang periode ${ }^{22}$ ). Men nogen skarp grænse mellem dansk og frisisk lader sig ikke trække op, de to nationaliteter boede blandet mellem hinanden, og først ved middelalderens slutning bli-

-) -Peter Jørgensen: tober die Herkunft der Nordfriesen (1946).

^) Sønderjyllands Historie I, $180 \mathrm{ff}$ (la Cour), Sach: anf. sted II, 134 ff, Historisk Tidsskrift 6. række IV, 344 ff. (P. Lauridsen), S $\varnothing n-$ derjydske Aarbøger 1893, 184 ff. (A. D. Jørgensen), Kong Valdemars Jordebog ed. Sv. Aakjær 93.

22) Sønderiyllands Historie I. 479 ff (la Cour), Historisk Tidsskrift 6. række IV, 333 (P. Lauridsen), "Peter Jørgensen, anf, sted $137 \mathrm{ff}$. 
ver der mulighed for at undersøge, hvordan forholdene har været $\mathrm{i}$ de enkelte sogne indenfor grænseomraadet.

Et af de vanskeligste problemer i ældre sønderjysk historie er det saakaldte svenskevælde i Sydslesvig. Kilderne er faa og meget vanskelige at tolke, og meningernes antal er legio. Men i hovedtrækkene lader begivenhederne sig dog med nogenlunde sikkerhed rekonstruere. I begyndelsen af det 10 . aarhundrede herskede i Hedeby en svensk konge Olaf, som havde sønnerne Gnupa og Gyrd. Kejser Henrik I gjorde 934 Gnupa skatskyldig, og kort efter drog kong Gorm imod Hedeby og fældede ham. Gnupas søn Sigtrygg skal efter Adam af Bremens udsagn væære blevet fordrevet af Hardegunde. Sigtryggs moder Asfrid Odinkarsdatter lod rejse to runestene over sin søn, Vedelspangog Gottorpstenene, hvoraf den første er ristet af en svensker ${ }^{33}$ ). Ogsaa paa de danske øer havde svenskefolket faaet fodfæste: Den lollandske runesten Sædingestenen afgiver vidnesbyrd om svenskernes tilstedeværelse her, idet den omtaler særsveerne: En anden lollandsk runesten, Tirstedstenen; er rejst til minde. om en mand, som fandt døden i Svitjod ${ }^{24}$ ).

Udgravningerne i Hedeby bekræfter historieskrivernes og runestenenes korte efterretninger; idet de viser, at kulturen her er stærkt svenskpræget ${ }^{25}$ ). Men stednavnene afgiver "et endnu værdifuldere vidnesbyrd. I den østlige del af Sydslesvig findes et betydeligt antal stednavne, sammensat af et personnavn og efterleddet -by. Samme navneform forekommer ogsaa paa de syddanske øer - især paa Lolland - men ellers kun sporadisk i det øvrige Danmark ${ }^{20}$ ); og danske, svenske:og tyske forskere

23) Lis Jacobsen: Svenskevældets Fald (1929), 57 f, 86, Otto Scheel: Die Wikinger. Aufbruch des Nordens $(138,233$ ff., Lis Jacobsen og Erik Moltke: Danmarks Runeindskrifter (1942), $10 \mathrm{ff} .$, hvor den omfattende litteratur er anf $\varnothing \mathrm{rt}$.

24) Lis Jacobsen og Erik Moltke: anf. sted (med udførlig litteraturfortegnelse).

25) Herbert Jankuhn: Haithabu (1937), 108 o. fl. a. st.

28) Namn och Bygd II (1914), 46 ff, hvor Marius Kristensen har givet en oversigt over det samlede stednavnestof af denne art, dog uden at drage den slutning, at det har forbindelse med svenskevældet. 
er $\mathrm{i}$ dag nogenlunde enige om, at disse svenskprægede navne stammer fra svensk bebyggelse, som paa en eller anden maade maa have haft forbindelse med svenskevældet. Ogsaa visse sønderjyske og syddanske dialektejendommeligheder - ikke mindst særegne accentforhold - synes at forudsætte en ikke ringe svensk indvandring til disse egne ${ }^{27}$ ).

For at kunne bedømme svenskevældets befolkningsmæssige betydning, maa man være klar over, hvilken udstrækning den svenske bebyggelse har haft. Navnestoffet tyder paa, at den i Sønderjylland væsentligst har omfattet Angel og Svans, men at der ogsaa i midtlandet har været svenske bosættelser, der skulde sikre den vigtige forbindelse mod vest. Den særprægede danske dialekt i Fjolde har enkelte forskere ment at kunne forklare, som et resultat af svensk paavirkning ${ }^{28}$ ). De svenske -by-former nord og syd for Slien er meget hyppige, og de enkelte kolonisationer ligger tæt. Bebyggelsens udstrækning ug tæthed peger saaledes i retning af, at svenskerne i Sydslesvig' har bosat sig i ret betydeligt omfang, og at der ikke blot er tale om en erobring, men om en kolonisation i stor stil. De fleste forskere er dog enige om, at det svenske herredørnme antagelig kun har strakt sig over ca. 4 aartier, fra ca. 900-940. Det zynes lidet sandsynligt, at en saa stærk kolonisation kan være sket paa saa relativ kort tid. Man kan vel ikke helt udelukke muligheden af, at den svenske indvandring kan være fortsat, efter at danskerne har generobret Hedeby, men mere nærliggende er det at formode, at de svenske bosættelser er begyndt allerede før oprettelsen af det politiske herredømme, ja, maaske netop har været en af forudsætningerne herfor ${ }^{29}$ ). Og-

En grafisk oversigt over navneformens udbredelse er givet af Vilh. la Cour: S $\varnothing$ derjyllands Historie I ad 288. Elof Hellquist: De svenska ortnamen på -by (1918), 127, Lolland-Falsters historiske Samfunds Aarbog 1923, $9 \mathrm{ff}$. (Marius Kristensen), 1928, 22 (Hans Kjær).

27) Erik Kroman: Musikalsk Accent i Danmark (1947), især $232 \mathrm{ff}$. junfr. Johs. Brøndum-Nielsen: Dialekter og Dialektforskning 94 og kort s. 22.

28) Kroman: anf. sted $242 \mathrm{f}$.

29) Herbert Jankuhn: Die Wehranlagen der Wikingerzeit zwischen Schlei und Treene (1937), $53 \mathrm{f}$. 
saa her bliver det arkæologien, der maa sige det afgørende ord.

\section{Tiden fra omkring 1200 til reformationen.}

Sønderjyllands nationale splittethed, som den kommer til udfoldelse i det 19. aarhundrede, har sine rødder langt tilbage. Tyskernes fremtrængen mellem Slesvig og Flensborg efter 1800 var først og fremmest en følge af den udvikling, som havde fundet sted i middelalderen, da den holstenske adel satte sig i besiddelse af storstedelen af det sønderjyske adelsgods og tilrev sig den højere administration $i$ landsdelen. Men baggrunden for dette holstenske fremstød var den almindelige politiske udvikling i Sønderjylland, først oprettelsen af et særligt grænsejarledømme, derefter dettes overgang til at blive en arvelig besiddelse for en gren af kongeslægten. Særlig skæbnesvanger blev det modsætningsforhold, som hurtigt opstad mellem de danske konger og de -sønderjyske hertuger, og som førte til, at disse paa forskellig maade søgte tilknytning til de holstenske grever, der snart kom til at spille en dominerende rolle nord for Ejderen.

Middelalderen igennem var Sønderjylland en kampplads, hvor begge parters hære udkæmpede voldsomme kampe. Og mellem slagene kæmpedes en kulturel og økonomisk kamp, som i sine virkninger maaske blev ligesaa farlige. Saavel i politisk som $i$ kulturel henseende var danskheden $i$ vigen $i$ aarhundrederne indtil reformationstiden. Et højdepunkt naaedes i 1440, da kong Christoffer maatte overlade hertug Adolf hele Sønderjylland. Christian I.s valg til dansk konge ændrede de ydre statsretslige rammer, idet kongen af Danmark nu atter var hertug i Sỏnderjylland, men med delingen i 1490 var vejen atter aaben for stridigheder. Enkelte ting kunde tyde paa, at kong Christian II havde en vis forstaaelse af den fare, som tyskhedens fremtrængen i Sønderjylland betød for Danmark og prøvede 
at modvirke denne, ligesom hans styre $i$ det hele taget havde et afgjort dansk præg. I en kancelliinstruks fra omkring 1522 hedder det, at breve fra Sønderjylland, der er skrevet paa dansk, skal registreres sammen med-breve fra Fyn og \#rø, og allerede fra januar 1520 skrives alle breve til Flensborg paa dansk, ligesom byens borgere benytter sig af dette sprog, da de i 1523 skriver til kongen. Ogsaa den holstenske adelsmand Wulf Pogwisch skriver i 1523 et dansk brev til Christian II. Frederik Is kansler fortæller iøvrigt, at der af kongen var udstedt befaling om, at der fra kancelliet kun maatte udstedes danske breve til Slesvig, ligesom der skulde ansættes danske skrivere paa slottene, og lensmændene skulde paase, at præsterne kun prædikede paa dansk. En saadan udtalelse er sikkert ment som en bebrejdelse mod Christian II og er i sin polemiske form en daarlig kilde, men de faktiske forhold kunde i hvert fald tyde paa, at paastanden om de danske breve er rigtig ${ }^{30}$ ). Betydning for fremtiden fik disse reformer dog ikke. Snart blev Christian II.s politiske lobebane brudt, og med Frederik I. fik riget og hertugdømmet en fyrste med tysk kulturpræg.

Den holstenske adels fremtrængen mod nord, der vel først er begyndt efter 1200, er sket gradvis, det har været en langsom proces, som vi i øjeblikket ikke kan følge i enkeltheder. Dog kan visse begivenheder af skelsættende betydning fremhæves, saaledes den pantsættelse kong Abels enke Mechtilde foretog i 1260, da hun pantsatte alt sit gods mellem Sli og Ejderen til hertugerne Johan og Gerhard. 1288 overlod hun grev Gerhard sin arvelod af godset til fuld ejendom, og 1325 blev Eckernförde og Dänischwohld af hertug Valdemar pantsat til grev Johan, der tre aar senere overlod pantet til grev Gerhard. Hermed var grundlaget for adelsvældet $\mathrm{i}$ egnene syd for Slien skabt ${ }^{31}$ ). De holstenske grever overlod efterhaanden størstedelen af de erhvervede omraader til de holstenske adelsmænd. I Dänischwold

30) Scandia 1939, 227 (Hvidtfeldt).

31) Sфnderjyllands Historie II, 101. 
nævnes i Gettorf sogn i det 14. og maaske allerede i det 13. aarhundrede slægten Schinkel, og i Dänischenhagen sogn forekommer slægten Reventlow og omkring samme tid slægten v. d. Wisch ${ }^{32}$ ). I Svans, der jo væsentligst var dansk kolonisationsomraade, havde slægten Sehested i 1332 besiddelser i Siseby og Ingersby, nogle faa aar senere ogsaa i Gammelby, Lcose og Schnaap, og i den følgende tid træffes en række andre adelsslægter paa halvøen. Kort efter 1500 er den næsten helt gaaet over $\mathrm{i}$ adelens og kirkens eje ${ }^{\mathrm{s3}}$ ).

Disse omraader syd for Slien var jo kun det danske kulturomraades forposter, en virkelig trusel for dette opstod først i det øjeblik, S'lien blev overskredet. Men dette lod heller ikke vente længe paa sig. Her blev vejen aabnet for holstenerne gennem forliget af 1313, da kong Erik overlod hertug Erik Valdemarssøn alt krongodset i Sønderjylland. Aaret efter lovede kongen ikke at tage flere „mænd“ i hertugdømmet. De politiske forhold i de aar, der fulgte umiddelbart efter, betegnede et foreløbigt kulminationspunkt for holstervældet, og snart kom de fleste af de gamle kongelige omraader, først og fremmest kongelevet, i de holstenske adelsmænds besiddelse. De store adelsdistrikter opstod ${ }^{34}$ ).

Mens der næppe har været nogen dansk adel i omraaderne sydfor Slien, er der selvfølgelig danske herremænd paa gaardene i de gamle danske omraader nordfor. Fra Angel kendes saaledes slægterne Post, Skram, Bildt m. fl. Men snart maatte de vige pladsen for de holstenske adelsslægter, som gennem køb,

s2) Willers Jessen og Chr. Koch: Heimatbuch des Kreises Eckernførde (1928), 556, 563, 569.

s3) Chr. Koch: Volks- und Landeskunde der Landschaft Schwansen (1912), 42.

s4) Hist. Tidsskrift 2. r. II (1848), 259 ff. (Velschow). Werner Carstens har i Zeitschrift LXIII (1935), 66-103, foretaget en indgaaende unders $\varnothing$ gelse af den holstenske adels historie $i$ middelalderen. Han fremhæver her, at mange holstenske adelige opgav deres besiddelser $i$ det gamle Holsten, i Vagrien og i Elbmarsken for at faa penge gjort frie til godserhvervelser i Slesvig, hvor adelen mod at yde rostjeneste var fri for offentlige afgifter og pligter, mens rostjenesten i Holsten

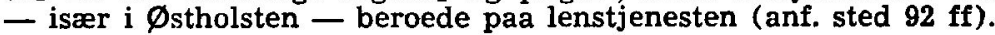


giftermaal og pantsættelser kom i besiddelse af næsten hele det angelske adelsgods. Omkring 1450 optræder i Angel saaledes mænd af slægterne Ahlefeldt, Pogewisch, van der Wisch, Sehested, Krummedige og mange flere $^{\mathrm{s5}}$ ). Ogsaa til Nordslesvig naaede den holstenske adel ret tidligt. Tørning, Varnæs birk, og Søgaard med Lundtoft herred var allerede i det 14. aarhundrede paa deres hænder, og af de 37 adelige, som i 1358 boede paa Sundeved og Als, var ca. $1 / 3$ af fremmed oprindelse, mens resten tilhørte den gamle sønderjyske adel ${ }^{36}$ ). Men Nordslesvig adskiller sig dog paa afgørende maade fra Sydslesvig, idet holstenerne her endnu $i$ begyndelsen af det 16. aarhundrede kun sad inde med enkelte af herregaardene, især de større, mens der stadig var danske herremænd paa de smaa herregaarde der ikke mindst fandtes paa Sundeved og Als og i Haderslev amt. Registret over plov- og frøken-skatten 1543 giver et vist begreb om forholdet mellem danske og sønderjyske paa den ene side og holstensk-tyske adelsmænd paa den anden side i aarene lige efter reformationen ${ }^{\mathrm{s}}$ ).

\begin{tabular}{lccc} 
Haderslev len $\ldots \ldots \ldots \ldots$ & $\begin{array}{c}\text { dansk- } \\
\text { sønderjyske }\end{array}$ & $\begin{array}{c}\text { holstensk- } \\
\text { tyske }\end{array}$ & usikre \\
Tørning len $\ldots \ldots \ldots \ldots \ldots$ & 10 & 10 & \\
Aabenraa len $\ldots \ldots \ldots \ldots \ldots$ & 2 & 1 & 1 \\
Sønderborg len $\ldots \ldots \ldots \ldots$ & 12 & 3 & 1 \\
Tønder len $\ldots \ldots \ldots \ldots \ldots$ & 12 & 6 & 1 \\
\cline { 2 - 5 } & 44 & 21 & 5
\end{tabular}

as) Sydslesvig II:: Angel (1945), 201 (Hvidtfeldt).

s6) Louis Bobé: Slægten Ahlefeldts Historie I (1897-1912), XLIII.

s7) F. Falkenstjerne og Anna Hude: Sønderjydske Skatte- og Jordebøger fra Reformationstiden (1895-99), $417 \mathrm{ff}$. Jvnfr. Landregistret fra 1543 (Neues Staatsbürgerliches Magazin III (1835), 74 f.) og restanceregistret over frøkenskatten 1549 (Zeitschrift XXV (1895), 221-223), hvor der findes lister over sønderjyske adelsmænd fra samme tid. Lensmændene (de tilhørte slægterne Rantzau, Ahlefeldt og van der Wisch) og gods, der tilhørte bogerlige, samt rent kirkeligt gods er ikke medtaget. Til de dansk-s $\varnothing$ nderjyske godsejere er henregnet alle de, der var af sønderjysk eller dansk uradel. Iøvrigt kan det undertiden være vanskeligt at afg $\varnothing \mathrm{re}$, til hvilken kategori de paagældende skal henf $\varnothing$ res. Enkelte af herremændene var ikke bosiddende i det amt, hvorunder de opf $\phi$ res. 
Oversigten viser, at den dansk-sønderjyske adel i ikke ringe grad har holdt sig i Nordslesvig, især i den vestlige del af landet og paa Als, altsaa i de omraader, som helt eller delvis hørte under kongerigske stifter. Ser man derimod paa, hvem der ejer de enkelte godser, tegner der sig et noget andet billede. De store godsbesiddelser som Gram, Søgaard og Søbo var paa tyske hænder, mens den danske adel især havde de smaa adelsgaarde eller de saakaldte frigaarde. Besidderne af disse adskiller sig i økonomisk og social henseende kun i ringe grad fra de talrige storbønder, der tilhørte gamle, vidtforgrenede slægter og spillede en betydelig rolle indenfor landsdelens retslige liv.

De sønderjyske hertuger omgav sig $i$ ældre tid med mænd af indfødt dansk adel. Men fra det 14. aarhundredes midte blev de ledende stillinger væsentligst beklædt af holstenere ${ }^{\mathbf{s}}$ ). Ogsaa de højere embedsmænd indenfor lokaladministrationen først og fremmest amtmændene - tilhørte i det 15. aarhundrede næsten udelukkende de holstenske adelsslægter. I privilegierne af 1460 lovede hertugen kun at ville give verdslige og gejstlige len i hertugdømmerne til indfødte, og disse regler bekræftedes i 1524, da det udtrykkelig blev fastslaaet, at embederne var forbeholdt landets adel ${ }^{39}$ ). I kongeriget fandtes der lignende regler, som dog ikke blev overholdt. I Sønderjylland gik det anderledes. Hvorledes forholdene har været før 1460, lader sig ikke udrede $\mathrm{i}$ enkeltheder; dertil er oplysningerne for spredte. Men de faa amtmænd, der kendes fra Nordslesvig i tiden 1400-60, tilhører alle de førende holstenske adelsslægter: Ahlefeldt, von der Wisch, Split, von Thienen, Krummedige, Buchwald, von Qualen og Reventlow. Og som det var at vente, skete der ingen ændring i dette forhold efter 1460, da der kan udarbejdes næsten fuldstændige fortegnelser over amtmænde-

s8) Zeitschrift VIII (1878), 125 ff. (Michelsen).

s9) Falck: Sammlung der wichtigsten Urkunden welche auf das Staatsrecht der Herzogthümer Schleswig und Holstein Bezug haben (1847), 22 f. 43 f. 
ne i de fire nordslesvigske hovedlen. Fra dette aar og til $153 \hat{0}$ kendes følgende amtmænd:

\section{Haderslev Aabenraa S $\varnothing$ nderborg Tønder}

$\begin{array}{llll}\text { Ahlefeldt } & 2 & 2 & 3 \\ \text { v. d. Wisch } & 1 & 2 & \\ \text { Stake } & 1 & & \\ \text { Rantzau } & 2 & 2 & 1 \\ \text { Heest } & 1 & & \\ \text { Blome } & 1 & & 1 \\ \text { Pogwisch } & & 2 & 1 \\ \text { Reventlow } & & & 1 \\ \text { Brockdorff } & & & \\ \text { von Kampen } & & & 1 \\ \text { Sture } & 1 & & 1 \\ \text { Lindow } & & & \\ \text { Holk } & & & \end{array}$

Af de 13 repræsenterede slægter har de 9 tilhørt holstenske adelsslægter, 4 (Holk, Lindow, Sture og von Kampen) den sønderjyske uradel. Men mens den sønderjyske adel kun er repræsenteret med ialt 4 personer, har holstenerme ikke mindre end 31 personer, et forhold, der er endnu mere grelt $i$ betragtning af, at de dansk-sønderjyske adel endnu i dette tidsrum var talmæssigt dobbelt saa stærkt repræsenteret i Nordslesvig som den tysk-holstenske. I Sydslesvig var forholdet endnu mere udpræget; i Gottorp amt fandtes i det paagældende tidsrum ingen amtmand af sønderjysk rod, i Flensborg amt een eller to. Ogsaa her er det Rantzauer og Ahlefeldter, der dominerer ${ }^{40}$ ).

Den verdslige magt i Sønderjylland var saaledes udelukkende i hænderne paa den holstenske adel, som ogsaa besad en stor del af den sønderjyske jord. Men i den middelalderlige stat var der foruden konge og herremænd en tredie - jævnbyrdig -faktor, hvis rige baade var af denne verden og den hinsides, kirken. Den havde vidtudstrakte jordbesiddelser og stor poli-

40) Zeitschrift VIII, 127 ff. (Michelsen), Ludwig Andresen: Bürgerund Einwohnerbuch der Stadt Tondern bis 1869 (1937), 136 f., W. Marstrand: Aabenraa (1933), 120. Oplysningerne i de anførte værker er suppleret med materiale hentet fra samtidige kilder. 
tisk magt, og dens indflydelse paa massermes aandelige liv og tankegang var overvældende. Gejstlighedens nationale afstamning er derfor et spergsmaal af ikke ringe betydning for forstaaelsen af brydningen mellem dansk og tysk i middelalderen. Materialet til belysning heraf er dog meget knapt, det er næsten kun om den højere gejstlighed, biskopper og domkapitlets medlemmer, at vi har nogen viden.

I det 13. aarhundrede var biskopperne overvejende af dansk afstamning, men $\mathrm{i}$ begyndelsen af det 14 . aarhundrede sker der en ændring i dette forhold, og af de 14 mænd, der i tiden 13081541 har beklædt den slesvigske bispestol, var højst to af dansk afstamning, 5 tilhørte holstenske adelsslægter, to var født i Tyskland, to i Holsten, en i Svans, og en stammede fra Italien ${ }^{41}$ ). For Nordslesvig har spørgsmaalet iøvrigt ikke saa stor betydning som for Sydslesvig, idet hele Vestslesvig til syd for Tønder laa under Ribe stift, mens Als og Ærø hørte under biskoppen i Odense.

Ogsaa i det slesvigske domkapitel kom den tysk-holstenske adel hurtigt til at spille en fremtrædende rolle. Fra 1242-1542 kendes ialt 279 medlemmer af kapitlet, og heraf kan de 60 med sikkerhed henfores til adelige slægter, mens flere andre maa formodes at have været adelige ${ }^{12}$ ). Af de 60 tilhørte ikke mindre end de 39 holstenske adelsslægter, 10 tyske, 5 sønderjyske, mens der intet med sikkerhed kan siges om de 6. Og her gælder det samme som ved amtmændene: det er enkelte holstenske adelsslægter, der spiller en altdominerende rolle. Slægten Ahlefeldt var saaledes repræsenteret med 6 medlemmer. Buchwald og Sehested hver med 5, Pogwisch og Rantzau hver med $\left.\operatorname{tre}^{49}\right)$. Om de domherrer, der ikke kan henføres til kendte adels-

4) Aage Dahl: Sønderjyllands Bispehistorie (1933), 8-20, Slesvigs delte Bispedømme (1949), 13 ff. (Johanne Skovgaard).

42) Klaus Harms: Das Domkapitel zu Schleswig von seinen Anfängen bis zum Jahre 1542 (Schriften des Vereins für schleswig-holsteinische Kirchengeschichte 1. r. VII, 1914), 27-32. Harms beregninger med hensyn til domherrer af tvivlsom adelig oprindelse er sikkert alt for $h \phi j$, hvad en gennemgang af de af ham anf $\phi$ rte personer viser.

43) Harms: anf. sted 28-30. 
slægter, foreligger der kun meget faa oplysninger, men listen over det slesvigske kapitels medlemmer taler dog sit tydelige sprog om den tysk-holstenske dominans indenfor den højere gejstlighed i Slesvig stift. Af de ca. 185 kanniker, der har været ved kapitlet i tiden ca. 1400—1542, synes kun nogle og tyve efter navnene at dømme at være af dansk-sønderjysk oprindelse, nemlig 5 medlemmer af den sønderjyske adel og 18 mænd med danskklingende patronymika. Selvom disse tal er og maa være behæftet med stor usikkerhed, og antallet af folk af dansk oprindelse maaske kan have været større ${ }^{44}$ ), er det dog hævet over enhver tvivl, at kapitlet i Slesvig i det 15 . aarhundrede var ganske overvejende tysk, baade af afstamning og uddannelse. Og forholdet har næppe været væsentligt anderledes i det 14. aarhundrede ${ }^{45}$ ).

Betragter man prælaturerne for sig, er forholdet omtrent det samme, men som det paa forhaand var at vente, spiller den tysk-holstenske adel her en særlig fremtrædende rolle. Fra 1343 -1542 kendes ialt 17 provster, hvoraf 8 tilhørte den holstenske adel, 1 den tyske; af de 13 diakoner var 6 holstenske adelige, af de 14 kantorer var 3 holstenske adelsmænd og to medlemmer af den tyske adel. Skatmesterens prælatur var særligt eftertragtet, og af 7 thesaurii i tiden 1474-1541 tilhørte de 5 den holstenske adel ${ }^{46}$ ). Ogsaa provsterne over Barvedsyssel og Vidaa provstier var væsentlig tyskere, i Barvedsyssel synes 13 af de 16 provster efter 1400 at have været tyske, mens der i Vidaa provsti var en forholdsvis stærk dansk repræsentation, nemlig 4 danske mod 5 tyske. Provsterne var især af borgerlig byrd,

4) En saadan beregning, som den her foretagne, hvor der kun bygges paa personernes navneformer, er selvfølgelig meget usikker, idet det i mange tilfælde maa blive et skøn, om et navn er dansk eller tysk, ligesom der naturligvis intet er $i$ vejen for, at en dansk mand kan have et tysk navn og omvendt. De anf $\varnothing$ rte tal maa derfor ikke betragtes som eksakte statistiske tal, men kun som et fingerpeg. Om hovedpaastandens rigtighed kan der imidlertid ingen tvivl være.

45) Harms: anf. sted 129-156. Vikarerne er ikke medtaget i opg $\phi-$ relsen.

46) Harms: anf. sted 50 f., 60, 65, 71, 147 f. 
men ogsaa enkelte holstenske adelsmænd forekommer i disse stillinger ${ }^{47}$ ).

Naar man betragter den række af domherrer, hvis navne er bevaret til vor tid, vil man ikke tro, at der er tale om kapitelsmedlemmer $i$ et stift, hvis indbyggere overvejende var danske. Og kapitlets fortyskning virker endnu mere grelt paa baggrund af forholdene $i$ den ovrige del af landet, hvor der i senmiddelalderen næsten kun sad danske mænd paa bispestolene, ligesom ogsaa domkapitlerne havde forbavsende faa medlemmer af udenlandsk herkomst ${ }^{48}$ ). Kapitlet valgte almindeligvis selv sine medlemmer, men paven kunde dog ogsaa besætte embederne ved provision, ligesom hertugen kunde gøre sin indflydelse gældende. Det forklarer, hvorledes kapitlet, engang fortysket, beholdt sit tyske præg, men ikke hvordan det blev tysk. Havde domkapitlet endda, som tilfældet var ved flere tyske kapitler, været forbeholdt adelen, vilde fortyskningen have været en naturlig følge af den holstenske adels sejrrige fremtrængen over hele Sønderjylland. Men størstedelen af kannikerne var uden tvivl borgerlige. Det kom her til at veje tungt, at de vigtigste og største byer havde en stærk fortysket overklasse.

Biskopper og domherrer kom ikke $\mathrm{i}$ berøring med menigmand i stiftets sogne. Her var det udelukkende sognepræster og munke, der skulde tage vare paa menighedens aandelige liv. Det vilde have været af særlig betydning, om man kunde have belyst den lavere gejstligheds nationale afstamning. Oplysningerne om sognepræsterne er imidlertid saa spredte og faa, at det her er umuligt at faa virkelig faste holdepunkter $\left.{ }^{49}\right)$. Det er vel i og for sig mest nærliggende at antage, at de fleste var af sonderjysk rod, men selvom de saaledes var danske af afstamning, blev de dog $\mathrm{i}$ deres uddannelse stærkt præget af. tysk kultur, enten det nu var ved kapitlets skole i Slesvig og Haders-

4) Smstds.: 148-151.

48) Nordisk Kultur II (1938), 50-51 (Aksel E. Christensen).

40) Slesvigs delte Bispedømme (1949), $141 \mathrm{f}$. 
lev eller ved tyske universiteter, de fik deres lærdom. De der var født i Barvedsyssel provsti skulde iøvrigt søge til skolen i Haderslev ${ }^{30}$ ).

Lidt anderledes ligger forholdet med hensyn til klostrene. De sønderjyske klostre var oprindelig nøje knyttet til de kongerigske og hørte $i$ administrativ henseende sammen med dem. Flere af dem var datterklostre af de store danske klostre, og der er ingen tvivl om, at munkene $i$ ældre tid $i$ langt overvejende grad har været danske. Af herreklostrene er nonneklostrets St. Johannes paa Holmen ved Slesvig, der tilhørte benediktinerordenen, allerede tidligt blevet fortysket. De navne, der nævnes i det 15. aarhundrede, tilhører næsten alle den holstenske adel, især slægten Smalsted, og viser iøvrigt, at klostret allerede før reformationen var beregnet for adelige damer ${ }^{51}$ ). Af de to andre herreklostre har cistercienserklostret Løgum - datterkloster af Herrevad og beliggende i Ribe stift - næppe nogensinde været fortysket. De abbeder, der kendes, bærer da ogsaa væsentligst danske navne ${ }^{52}$ ). Ryd kloster, der ogsaa tilhørte cistercienserordenen, var datterkloster af Esrom. At den aarbog, der i den sidste halvdel af det 13. aarhundrede blev skrevet i Ryd, er blevet til i et dansk kloster, bærer dens voldsomme had til tyskerne vidnesbyrd om $^{53}$ ). Endnu i 1424 aflagde klostrets abbed Oluf, der var født i Danmark, under kejserprocessen vidnesbyrd til gunst for den danske konge. Han udtalte bl. a.: „.... quod tota Jucia australis habet idem ydioma, quod habet reliquum regni Dacie et eisdem legibus et constitucionibus utitur, quibus jucia borealis.... “54). Men da holstenerne kort efter fik herredømmet, synes klostret at være blevet nært knyttet til sejrherrerne. Abbed Olav fortsatte dog som abbed (nævnes endnu

50) Smstds.: $160-62$.

B1) Aug. Sach: Geschichte der Stadt Schleswig (1875), 85-93.

52) Sønderjydske Aarbøger 1945, 36 f. (M. Mackeprang).

${ }^{53}$ ) Trykt i Annales Danici medii ævi ed. Ellen Jørgensen (1920), 14-17, 62-125. Oversættelser i Nye danske Magazin V, 161 og $\mathbf{M}$. Lorenzen: Gammeldanske Krøniker.

s4) Scriptores rerum Danicarum VII, 417. 
1440), men de politiske omvæltninger har uden tvivl haft indflydelse paa munkesamfundets nationale sammensætning ${ }^{55}$ ). Sammen med disse to herreklostre maa ogsaa nævnes antoniterklostret Maarkær i Angel - de flæskeglade munkes kloster som i 1391 blev grundlagt af udsendte missionærer og almissesamlere fra Antonius præceptoriet Tempzin i Mecklenborg ${ }^{56}$ ). De første munke har saaledes afgjort været tyske, men senere fik klostret stærk tilknytning til kongeriget, hvor det 1470 fik overdraget Vor Frue kirke i Præstø, og dets indsamlere hentede det gode danske flæsk til Angel, en virksomhed der hudflettedes i reformationstidens kendte satire: „En Historie om Peder Smed og Asser Bonde ${ }^{57}$ ). Naar de maarkærske munke terminerede i kongeriget, synes det at være et vidnesbyrd om, at klostret ogsaa har rummet dansktalende munke.

Af tiggerordenerne havde dominikanerne klostre i Slesvig og Haderslev, franciskanerne i Slesvig, Tønder, Flensborg og Husum (stiftet 1494). Om sortebrødreklostrene foreligger der kun meget faa efterretninger ${ }^{\mathrm{s}}$ ). Derimod er det muligt at kaste lys henover de nationale modsætninger indenfor visse af franciskanerordenens klostre i senmiddelalderen. Brydningerne hænger delvis sammen med kampen mellem konventualer og observanter. I det sidste aarti af det 15. aarhundrede var der stærk uro i klostret i Slesvig, og der fremførtes bl. a. klager over fire danske munke i klostret. Der har antagelig ligget nationale rivninger bag stridighederne, som forte til, at klostret i 1499 blev bragt til observans, idet der indførtes nye munke - antagelig danske. Faa aar senere blev klostret dog af hertug

s5) Sejdelin: Diplomatarium Flensborgense I (1865), 413-16, Johannes Lindbæk: De danske Franciskanerklostre (1914), 112 ff. Flere af abbederne efter 1458 bærer tyske navne (se fortegnelsen i Jensens Kirchliche Statistik III, 954).

s8) Jahrb. und Jahresbericht des Mecklenburgischen Vereins für Geschichte XV (1850), 150 ff.

s7) S $\varnothing$ nderjydske Aarb $\varnothing$ ger $1894,147-156$ (A. D. Jørgensen), Peder Smed og Adser Bonde ed. Svend Mogensen (1936), BI-II.

${ }^{68}$ ) Om klostret i Slesvig se Sach: anf. sted 80 f., de der anførte 6 navne paa munke og priorer er væsentligst tyske. 
Frederik sammen med klostrene i Kiel og Husum (og senere Lunden i Ditmarsken) lagt under kustodiet Kiel, der næsten var helt losnet fra forbindelsen med den danske provins ${ }^{59}$ ). Franciskanerklostret $i$ Flensborg stod under kampene $i$ begyndelsen af det 15. aarhundrede paa kongens side. Om klostret efter holstenernes erobring er blevet fortysket, vides ikke. Da det i 1496 blev bragt til observans, skete det paa kong Hans' og hertug Frederiks bekostning, og med danske munke. De tyske munke, der var i klostret, forlod dette uden at tage afsked, og generalvikaren gav kongen skriftligt løfte om, at der ikke skulde optages fremmede munke uden kongens vilje. Senere under Christian II blev der gjort forsøg paa atter at indføre „fratres aliene nacionis ad conventum Flensburgensem". Baggrunden for denne aktion er uden tvivl det spændte forhold mellem Christian II og hans onkel, der vel først og fremmest var bestemt af politisk-dynastiske modsætninger, men dog ogsaa havde et vist nationalt islæt, der f. eks. gav sig udslag i kongens danskprægede politik i Sønderjylland $d^{80}$ ) og i hertugens forsøg paa at løsrive flere af de sønderjyske klostre fra forbindelsen med kongeriget. Kongen vendte sig i en skrivelse til generalvikaren skarpt mod forsøget paa at fortyske Flensborg klostret, og anslaget mislykkedes da ogsaa ${ }^{61}$ ). Ogsaa i Tønder medførte indførelsen af observansen i 1503, at klostret blev forsynet med danske munke. Amtmanden paa Tønderhus, Claus von Ahlefeldt, bad fire aar senere hertugen om at udvirke, "dat de musten brodere hyr ime klostere to Lutkentunderen (m)ochten dudesche brodere syn, were eyn sodant vor des klosters groeteste nutte". Hvad der ligger bagved anmodningen, lader sig nu næppe fastslaa, men snarest er det vel den holstenske adelsmands $76 \mathrm{f}$.

39) Johs, Lindbæk: De danske Franciskanerklostre (1914), 105 f,

60) se side $172 \mathrm{f}$.

81) Lindbæk: anf. sted 111-116, 76-78, Zeitschrift XIV (1884), 178 -188 (A. Wolff), Seidelin: anf. sted II, $94 \mathrm{f}$. Brevet er antagelig fra omkring 1522, se Repertoriet 2. r., VII (1935), 300 f. og Zeitschrift anf. sted. 
uvilje mod de danske munke, der her kommer til udtryk. Nogen forandring blev næppe udført, i hvert fald var klostrets to sidste gardianer - Hans Olafson og Niels Thybo - uden al tvivl danske ${ }^{\text {6z }}$.

Betragter man den sønderjyske kirke i middelalderen, faar man et stærkt indtryk af højgejstlighedens fortyskning. Klostrene var fra først af antagelig danske, men ogsaa her har den tyske fremtrængen efterhaanden gjort sig gældende, dog saaledes, at der indenfor franciskanerordenen finder en dansk reaktion sted i forbindelse med indførelsen af observansen. Da reformationens uvejr bred ind over Sonderjylland, var klostrene i Nordslesvig (om Haderslev foreligger der ingen oplysninger) og Flensborg uden tvivl dansk.

Naar man vil forstaa de ændringer, der i middelalderen er sket i de sønderjyske befolkningsforhold, spiller udviklingen i købstæderne en betydelig rolle. Erfaringen baade fra Danmark og udlandet viser, at byerne altid har modtaget et betydelig storre indslag af fremmed blod end den fast bosiddende landbefolkning. Borgernes vigtigste næring var haandværk, handel og skibsfart, og udøverne af disse erhvervsgrene kom i ældre tid vidt omkring. Mange kom paa denne maade til fremmede lande, hvor de ofte slog sig ned, og paa tilsvarende vis bragte handelsforbindelserne mange udlændinge til byerne. Ogsaa haandværkerne maa allerede $i$ middelalderen antages at have været ret mobile.

Da købstæderne havde en stærk kulturel indflydelse paa landsognene - en paavirkning der formidledes ad mange forskellige kanaler - er spørgsmaalet om indvandringen til de sønderjyske købstæder af meget stor betydning. S'aa meget mere beklagelsesværdigt er det derfor, at materialet til dets besvarelse er saa ringe, ligesom der kun foreligger meget faa undersøgelser af problemet. Eckernförde og Husum frembyder

62) Nordelbingen VII (1928), 8-9 (L. Andresen), Lindbæk: anf. sted 108 f., 75 f. Repertoriet 2. r., VI (1934), 231. 
i denne forbindelse ringe interesse, idet de fra første færd har haft en næsten ren tysk og frisisk befolkning ${ }^{65}$ ). Slesvig har uden tvivl været den by, hvor spørgsmaalet dansk-tysk tidligst har været brændende. Byens ældre historie frembyder store problemer. Ikke mindst har der blandt forskerne været stor uenighed om dens beliggenhed ${ }^{84}$ ). Den ældre teori om to samtidige byer ved den indre Sli: Hedeby syd for Slien og Slesvig nordfor er nu næsten helt opgivet, idet tyske arkæologers intensive undersøgelser - først og fremmest de store Hedeby-udgravninger - har gjort det sandsynligt, at ogsaa det ældste Slesvig har ligget sydfor Slien, og at Hedeby og Slesvig er samme navne for byen, hvilket ogsaa fremgaar af udtalelser af Ethelwerd og Adam af Bremen. Fundene viser, at byen nordfor Slien endnu har eksisteret omkring $1050^{65}$ ).

Hedeby-Slesvigs fremtrædende position skyldes dens stilling som handelsmidtpunkt med stærke forbindelser mod nord og vest $\left.{ }^{88}\right)$. Allerede dette forhold gør det sandsynligt, at dens befolkning fra først af har haft et stærkt internationalt præg, hvilket ogsaa fremgaar af Rimberts Vita Anskarii i forbindelse med omtalen af den tilladelse, som Ansgar fik til at bygge kirken i Slesvig, hvor det bl. a. hedder: „Sliaswich vocato, ubi ex omni parte conventus fiebat negotiatorum.... Multinamque ibi antea erant christiani, qui vel in Dorstado vel in Hammaburg baptizati fuerant, quorum quidam primores ipsius vici habebantur.... et negotiatores tam hinc quam ex Dorstado locum ipsum

os) Angaaende Eckernförde se Sach III, 211-14, ang. Husum Sdj. Aarb. 1944, 7 (Bjerrum).

64) Redeg $\varnothing$ relse for de tidligere synspunkter i Herbert Jankuhn: Die Wehranlangen der Wikingerzeit zwischen Schlei und Treene (Vorund frühgeschichtliche Untersuchungen aus dem Museum vorgeschichtlicher Altertümer in Kiel. Neue Folge I, 1937) 6-31.

$\left.{ }^{65}\right)$ Jankuhn: anf. sted $82 \mathrm{ff}, 281 \mathrm{ff}$, samme: Haithabu. Eine germanische Stadt der Frühzeit (1937), 52 ff, 60 f, Nordisk Kultur XVIII (1937), $7 \mathrm{ff}$ (Schück).. En noget afvigende mening: to forskellige bebyggelser er hævdet af Frahm (Zeitschrift LXII. (1934), 156-212, jvnfr. LXIV (1936), 3 f. Spørgsmaalet er ogsaa behandlet af Roar Skovmand: Festskrift til Erik Arup (1946), 39 f., J. Bjerrum og Th. Ramskou: Danmarks Sydgrænse (1948), $24 \mathrm{f}$.

$\left.{ }^{60}\right)$ Hugo Matthiessen: Middelalderlige Byer (1927), 17-36. 
libere expeterent". Forskellige udtalelser hos Adam af Bremen tyder i samme retning ${ }^{67}$ ). De frankiske annaler fortæller, at Gudfred i 808 ødelagde landsbyen Reric, hvis købmænd han forte bort. $\mathrm{Da}$ det udtrykkelig nævnes, at han fra Reric drog til Sliesthorp, der vel maa være identisk med Slesvig, er den tanke nærliggende, at købmændene er blevet anbragt der. Det senere svenske og tyske herredømme har vel ogsaa medført en forøget folkeblanding, selvom det tyske herredømme, først under Henrik I, senere under Otto II, kun blev af kort varighed, og rigtigheden af Adam og Bremens oplysning om en saksisk koloni i Slesvig maa anses for tvivlsom ${ }^{68}$ ). Ogsaa de arkæologiske fund bærer tydeligt præg af en by med stærke internationale forbindelser ${ }^{\text {ag }}$ ).

Med hensyn til Slesvigs flytning til dens nuværende plads nordfor Slien er kilderne fuldstændigt tavse, men den har antagelig fundet sted i sidste fjerdedel af det 11. aarhundrede. Om aăsagerne vides intet, men det kan tænkes, at flytningen hænger sammen med de vendiske angreb, og at man har valgt den trafikmæssigt daarlige position, fordi den strategisk frembød adskillige fordele $\mathrm{e}^{70}$ ). Om de mennesker, som befolkede det nye Slesvig i de første aartier, tier kilderme ganske. Det vil paa forhaand være nærliggende at formode, at den nye bebyggelse ligesom Hedeby har haft et ret internationalt præg med mennesker af baade dansk og fremmed afstamning. Dels var de gamle handelsforbindelser ikke afbrudte, dels maa man regne med, at en del af den gamle bys mennesker har dannet kernen i det nye borgerskab ${ }^{71}$ ). Det væsentligst danske opland har uden tvivl

07) Otto Scheel og Peter Paulsen: Quellen zur Frage SchleswigHaithabu (1930), 70. Ilse Schneider: Stadtgeographie von Schleswig (1934), 8, .69, hvor de forskellige kildesteder anf $\varnothing \mathrm{res}$.

$\left.{ }^{68}\right)$ Sønderjyllands Historie I, 227-29, $245 \mathrm{f} ., 263 \mathrm{f}, 275-279$, Ilse Schneider: anf. sted 8-16, Jankuhn. Haithabu: 52-59.

09) Jankuhn: anf. sted, især $137 \mathrm{f}$.

70) Zeitschrift LXII (1932), $181 \mathrm{ff}$.

71) Frahm har i Zeitschrift LXII (1934), 188-90 hævdet, at $\gg$ die Nordstadt fra første færd var seine Gründung deutscher Kaufleute u. Handwerkerk. En saadan paastand, for hvilket intet bevis fremf $\varnothing-$ res, er i og for sig meget usandsynlig. Den bruges dog af forfatteren 
afgivet en del af sit menneskemateriale til den nye by, som maa have gennemgaaet en stærk udvikling i det første aarhundrede af sin eksistens, idet den 1196 havde 7 kirker $^{72}$ ). Og de talrige danske udtryk, der forekommer i den ældste - paa latin affattede - slesvigske byret afgiver et tydeligt og hidtil ikke modbevist vidnesbyrd om, at Slesvig i slutningen af det 12 . og begyndelsen af det 13. aarhundrede har været en overvejende dansk by med en befolkning, der væsentligst var dansktalende. Dette bekræftes ogsaa af de danske udtryk i det middelalderlige kildemateriale vedrørende Slesvig og en ret hyppig forekomst af danske marknavne ${ }^{73}$ ).

Flensborg og de nordslesvigske købstæder frembyder helt andre problemer end Slesvig. De er alle betydeligt yngre, og dog lader der sig intet sikkert sige om deres oprindelse. De forskere, som har behandlet problemet, er meget uenige, idet nogle mener, at byerne er opstaaet ved en jævn og rolig udvikling,

til at underbygge en hypotese om, at Slesvigs byret er af nederrhinsk oprindelse (Zeitschrift LXIV (1936), 1-99). Trods en indgaaende men ikke fyldestgørende - unders $\varnothing$ gelse er det dog langtfra lykkedes forfatteren at følge noget tilfredsstillende bevis for sin paastand. Den udenlandske indflydelse paa Slesvigs byret er jo, naar man tager byens historie i betragtning, paa forhaand meget sandsynlig, og ogsaa fra dansk side er der tidligere gjort opmærksom paa forholdet. (A. D. Jørgensen: Historiske Afhandlinger II (1899), 185 ff.) Frahm giver interessante bidrag til belysning af det fremmede indslag i byretten, men hans aprioriske opfattelse af denne som ikke-dansk gor hans behandling af problemet ensidig. Dette kommer f. eks. stærkt frem i hans mislykkede fors $\varnothing \mathrm{g}$ paa at bortforklare de danske ord i byretten, et fors $\phi \mathrm{g}$, der viser, hvor let en forsker kan komme til at g $\phi$ re vold paa det historiske kildemateriale, naar dette skal bringes $i$ overensstemmelse med en bestemt ide. Da Slesvig byret jo er blevet overf $\emptyset$ rt til en lang række danske købstæder, maa man haabe, at spørgsmaalet maa blive taget op til unders $\phi$ gelse af en dansk retshistoriker; forel $\phi-$ big kan der være grund til at fremhæve en udtalelse af dansk retshistories førstemand: $\$ . .$. naar man har villet hævde, at Byretten saa at sige ikke indeholder dansk Ret og staar i bestemt Modsætning til J. L., kan Rigtigheden heraf ikke anerkendes\& (Poul Johs. Jørgensen: Dansk Retshistorie (1940), 106).

72) Sach: Geschichte der Stadt Schleswig (1875), $64 \mathrm{ff}$.

73) P. G. Thorsen: De med jydske Lov beslægtede Stadsretter (1855), 1-20, Annaler for nordisk Oldkyndighed og Historie (1859), 234-261 (Chr. C. Lorenzen) med bemæerkninger af K. J. Lyngby (s. 261-72), Sach III, 218-226, Sønderjydske Aarb $\varnothing \mathrm{ger} 1944,10 \mathrm{ff}$. (Bjerrum). 
og at deres opstaaen er betinget af samfærdselsforholdene eller en gunstig geografisk position (fjordbyerne). Andre mener, at vi ved de fleste byer staar overfor kolonisationer, bevidste byanlæggelser, efter tysk mønster eller endog af tyske kolonister. Det maa i denne forbindelse stærkt fremhæves, at disse byer er opstaaet i et omraade, som var og i aarhundreder har været rent dansk kulturomraade, og spørgsmaalet vil derfor ikke kunne besvares definitivt, før der engang foreligger indgaaende undersøgelser over de danske købstæders oprindelse, herunder ogsaa omfattende sammenligninger med de samtidige tyske og nordiske bygrundlæggelser. Indtil det modsatte er bevist, har man lov til at regne med, at størstedelen af de danske købstæder ikke er grundlagt af kongen, af en privat grundejer eller af købmandssammenslutninger ${ }^{34}$ ), og selvom paavirkninger sydfra utvivlsomt har spillet en vis rolle ved udformningen af byerne og bysamfundet, er der i hvert fald næppe tale om tyske kolonisationer paa dansk kulturomraade. De nye danske byer frembyder forholdsvis faa lighedspunkter med de omtrent samtidige tyske bygrundlæggelser ved Østersøen ${ }^{25}$ ), og man maa vogte sig for at drage for vidtrækkende slutninger udfra tilfældige ligheder i byplanerne. Den historiske situation i Nordtyskland og i Danmark var vidt forskellig.

For $\mathrm{T} ø \mathrm{nders}$ vedkommende har Ludwig Andresen med stor styrke hævdet, at byen var grundlagt af tyske kolonister ${ }^{76}$ ), men teorien har aldrig været anerkendt af den danske forsk-

i4) Spфrgsmaalet er i korthed behandlet af Hugo Matthiessen i Medd. fra Foreningen til gamle Bygningers Bevaring 4. r. II, 1941, 5-16 og i Nordisk Kultur XVIII (1933), 49, 52.

75) Om disse se Fritz Rörig: Die Gründungsunternehmerstädte des 12. Jahrhunderts (i Hansische Beiträge zur deutschen Wirtschaftsgeschichte. Schriften der Baltischen Kommission zu Kiel IX, 1928), 243 -284. I Architekten XXIII (1921), 349-357 har Hugo Matthiessen paa grundlag af sammenligninger mellem byplanerne for de nordtyske byer og for K Kge hævdet, at Køge er anlagt under Erik Glipping med de pommerske kolonisationsbyer som direkte forbillede.

76) Geschichte der Stadt Tondern I (1939), 9-15. 
ning og er ogsaa nu opgivet fra tysk side $\left.{ }^{77}\right)$. Der er nu enighed om, at Tønder har udviklet sig lidt efter lidt, og at der ligger en lang udviklingsperiode mellem anlægget af de første bebyggelser og erhvervelsen af lybsk ret i $1243^{78}$ ). Om A a b e n r a a s oprindelse kan der næppe være tvivl. Fra et lille fiskerleje er den efterhaanden vokset frem til en købstad, idet den i det store og hele har udviklet sig paa samme maade som de ovrige østjyske fjordbyer ${ }^{70}$ ). Sø $\mathrm{nde} \mathbf{r}$ bor g s historie $\mathrm{i}$ middelalderen er saa godt som ukendt, men alt tyder paa, at den er en udpræget borgby, der er vokset op omkring det stærke Sønderborg slot, ligesom en del andre danske byers placering har været betinget af en kongelig borg. Mere uklart ligger forholdet ved $\mathrm{H}$ a derslev, som er opstaaet paa landsbyens (Gl. Haderslev) bymarker. Mens Sach mener, at Haderslev kan være en borgby ${ }^{80}$ ), har Th. $O$. Achelis hævdet, at byen er blevet til lidt efter lidt, og at den senere byplan ikke afspejler byens oprindelige struktur ${ }^{81}$ ). Hugo Matthiessen og den tyske historiker Fr. Fuglsang har derimod paa grundlag af ejendommeligheder i byplanen hævdet, at der maa være tale om et kunstigt anlæg, idet den sidstnævnte mener at kunne paavise, at tyske forbilleder har gjort sig gældende. Han tør deraf dog ikke slutte, at byen er anlagt af tyske „locatores ${ }^{\text {(82 }}$ ). Senere har Achelis sluttet sig til Fuglsangs opfattelse, idet han dog gaar videre end denne og siger, at det maa være tyske købmænd, som har grund-

77) Tønder gennem Tiderne (1943), 32 ff., 399, Sdj. Aarb. 1940, 299 ff. (Hvidtfeldt), Der Schleswig-Holsteiner 1943, $132 \mathrm{ff}$. (Scheel), jvnfr. ogsaa samme i Der Norden 1943.

78) I Tønder gennem Tiderne 32-46 har Vilh. Lorenzen dog hævdet, at der foruden det ældre Tønder, oprindelig en slags havneby til Møgeltønder, ogsaa er tale om et yngre Tønder, der er blevet til efter en bevidst planlæggelse af hertug Abel. Bevisf $\varnothing$ relsen er meget svag og langtfra overbevisende.

79) Hugo Matthiessen: Haderslev og Aabenraa (1925), 53 f., W. Marstrand, Aabenraa (1933), $67 \mathrm{ff}$.

Bo) Sach: Der Ursprung der Stadt Hadersleben (1892), $9 \mathrm{f}$.

8) Th. O. Achelis: Haderslev i gamle Dage I (1926), 12-14.

82) Hugo Matthiessen: Haderslev og Aabenraa (1925), 14, Heimatblätter aus Nordschleswig 1943 , nr. 4-6, 165. 
lagt Haderslev. Antydning af et bevis for denne ret opsigtsvækkende paastand anføres dog ikke. Denne meningernes mangfoldighed skyldes, at alle opfattelserne $\mathbf{i}$ virkeligheden kun bygger paa lose gisninger. Byplanen, omend den muligvis indeholder visse ejendommelige træk, beviser ingenlunde, at Haderslev er et kunstigt anlæg. Byen maa være anlagt $i$ 1100-aarene, antagelig omkring midten af aarhundredet, idet Saxo omtaler byen, og den oprindelige granitkirke maa stamme fra omkring $1150^{83}$ ). Men det er ikke sandsynligt, at der paa saa tidligt et tidspunkt skulde være tale om et kunstigt byanlæg, endsige en tysk kolonisation. Haderslevs beliggenhed udelukkede, at den kunde komme til at indtage nogen førende stilling som handelsby. Byretten fra 1292, der baade i sprog og indhold er rent dansk, er ogsaa et vægtigt indicium mod en saadan antagelse.

Flensborg frembyder endnu flere problemer end $\mathrm{Ha}-$ derslev, idet en del forhold tyder paa, at der er tale om to forskellige bydele, St. Maria sogn mod nord og St. Nicolai sogn mod syd, som først efterhaanden er vokset sammen til en enhed. St. Maria maa være ældst, idet det senest kan være opstaaet $i$ den sidste fjerdedel af det 12 . aarhundrede, mens Si. Nicolai antagelig stammer fra første halvdel af det 14. aarhundrede. Chr. Voigt, som har undersøgt disse forhold, mener desuden, at baade Nørretorvs og Søndertorvs placering og ejendomsforholdene paa torvet tyder paa, at begge bydele er grundlæggelser. St. Maria er en dansk kolonisation, mens den sydlige del formodes at være grundlagt af tyske købmænd ${ }^{84}$ ). Nørre-

83) Saxo siger $i$ anledning af kong Hothers drab: »cujus occasum perpes oppidi vocabulum indicat $\ll$. Med oppidum kan kun menes købstaden Haderslev, ikke landsbyen G1. Haderslev. Sach: Der Ursprung der Stadt Hadersleben, 8. Angaaende granitkirken se: Güttel: Die Marienkirche in Hadersleben (Studien zur schleswig-holsteinischen Kunstgeschichte I, 1935), 6-9.

84) Zeitschrift LXV (1937), 111-167. Allerede i 1909 hævdede W. Mohr i Flensburgs Ursprung, at Flensborg var en koloni, anlagt af tyskere omkring 1200. Alle hans beviser er dog uholdbare (se Voigt: anf. sted 126 f.) 
torvs placering i forhold til gaderne, først og fremmest hovedgaden, frembyder dog ikke saadanne ejendommeligheder ${ }^{85}$ ), at man paa det grundlag kan drage nogen slutning om et kunstigt anlæg. Hvis hypotesen om, at den sydlige bydel er et særligt anlæg fra første halvdel af det 14. aarhundrede, er rigtig, kunde formodningen om en koloni her synes sandsynligere. De personnavne, som vi kender fra tiden omkring 1400, viser, at der paa dette tidspunkt har været en del tyskere $\mathrm{i}$ byen, især $\mathbf{i}$ St. Nicolai, og det er nærliggende at formode, at dette ogsaa har været tilfældet $\mathrm{i}$ første halvdel af aarhundredet. ${ }^{86}$ ).

De befolkningsmæssige forhold $\mathrm{i}$ byen modsiger saaledes ikke $i$ og for sig hypotesen om en tysk grundlæggelse. Men kildematerialet giver heller ikke virkelige holdepunkter for en saadan.

Bortset fra Slesvig, hvor særlige forhold gør sig gældende, viser de sønderjyske byers ældste historie ${ }^{87}$ ), at disse er vokset langsomt ud af bondesamfundet, idet deres opstaaen er betinget af deres gunstige placering $\mathrm{i}$ landskabet eller $\mathbf{i}$ forhold til hovedfærdselsaarene. Der findes intet tvingende bevis for, at nogen af dem er kunstige anlæg. Men i byer, der er opstaaet paa denne maade, maa man antage, at den storste del af befolkningen stammer fra den nærmeste omegn, hvilket vil sige; at det er sønderjyder, der fra første færd har befolket de nordslesvigske byer og Flensborg, en antagelse, der almindeligvis ogsaa hævdes baade af den danske og den tyske forskning. Og at der ikke blot er tale om en formodning, bevises tilfulde af en række forskellige forhold. Marknavnene i de nordslesvigske byer giver saaledes et uomtvisteligt bevis paa disse byers oprindelige danske befolkning ${ }^{88}$ ). Et andet talende vidnesbyrd er by-

85) Angaaende torvet og dets placering i danske k $\phi b s t æ d e r, ~ s e$ Hugo Matthiessen: Torv og Hærstræde (1922).

86) Troels Fink i Festskrift til Knud Fabricius (1945), 13-29, Die Heimat 1935, 336, (Graef).

87) Husum og Eckernförde kommer ikke i betragtning, da de aldrig har hørt med til det danske kulturomraade.

88) Sdj. Stednavne I-IV (1931-1944). 
retterne, hvoraf den flensborgske er affattet paa dansk (ca. 1300), og den haderslevske foreligger $i$ oversættelse fra latin til dansk (1292), mens to latinske byretter fra Slesvig (12.-13. aarhundrede) og Aabenraa (1335) indeholder en mængde danske udtryk, der viser, at byernes sprog - ogsaa retssproget - paa affattelsestiden maa have været dansk. Oversættelsen til plattysk fandt først sted betydeligt senere, i Slesvig omkring 1400, i Flensborg senest $\mathrm{i}$ første halvdel af det 15. aarhundrede og $\mathrm{i}$ Aabenraa ca. $1450^{89}$ ). Kun Tonder indtager i denne forbindelse en særstilling, idet den lybske stadsret allerede i 1243 overførtes dertil. Det kan dog ikke skyldes, at befolkningen eller en større del deraf paa dette tidspunkt har været tysk. Som allerede vist var Tønder ikke en koloni, og intet tyder paa, at denne by $i$ befolkningsmæssigt henseende skulde have indtaget en særstilling blandt de nordslesvigske byer ${ }^{00}$ ).

Men selvom de nordslesvigske byer og Flensborg - delvis ogsaa Slesvig - i det 12. og 13. aarhundrede og endnu i begyndelsen af det 14. aarhundrede har været overvejende danske byer med en udpræget sønderjysk befolkning, kan der i den sidste del af middelalderen være sket en afgørende ændring i dette forhold. Denne periode var en storhedstid for Tyskland, hvor tysk kultur, tyske handelsmænd og adelsmænd trængte frem langt ud over Tysklands grænser. Ogsaa i hele Norden gjorde tyskerne - først og fremmest Hanseaterne - sig stærkt gældende. De beherskede handelen og spillede en dominerende politisk rolle. I Danmark blev den tyske indflydelse vel aldrig saa stærk som i Sverige og Norge, men ogsaa her havde

89) Poul Johs. Jørgensen: Dansk Retshistorie (1940), 105-12, E. Wohlhaupter: Rechtsquellen Schleswig-Holsteins I (Veröffentlichungen der schlesw.-holst. Univ.-Gesellsch. nr. 47, 1938), 17 ff. Byretter er bedst trykt i P. G. Thorsen: De med jydske Lov beslægtede Stadsretter for Slesvig, Flensborg, Aabenraa og Haderslev (1856). Sønderborg har haft sin byskraa, antagelig fra 1 . fjerdedel af det 15. aarhundrede, men den kendes nu ikke mere (Sdj. Aarb. 1942, 44, Hvidtfeldt).

80) Anguaende den lybske ret i Tønder se Stig Juuls redegørelse i Tønder gennem Tiderne (1943-44), $465 \mathrm{ff}$. 
tyske købmænd en stor del af handelen i deres hænder, og i mange købstæder findes $\mathrm{i}$ det 14 . aarhundrede et betydeligt tysk indslag i befolkningen. Det gælder især byerne ved Øresund og paa Skaanes sydkyst og Bornholm, hvilket fremgaar af de „tyske Kompagnier“, der oprettedes her ${ }^{91}$ ). I Vest-Danmark begyndte den tyske tilvandring noget senere, og bortset fra de sterre byer som Aalborg, Ribe og Odense har indvandringen sydfra her næppe været stor. I to saa betydelige byer som Aarhus og Viborg fandtes der saaledes kun faa udlændinge i

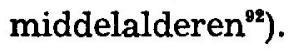

I Sønderjylland gjorde der sig særlige forhold gældende, idet de statsretslige og politiske forhold og den holstensk-tyske adels dominans naturligvis har lettet en indvandring af tyske købmænd og haandværkere. Der er da ogsaa gang paa gang ikke mindst fra tysk videnskabs side - blevet hævdet, at de sønderjyske byer i middelalderen er blevet delvis fortyskede ${ }^{05}$ ). Der kan heller ikke være tvivl om, at dette gælder for Slesvigs og delvis ogsaa for Flensborgs vedkommende. Dette undrer ikke i betragtning af Slesvigs ældre historie og Flensborgs førende stilling indenfor hertugdømmets økonomiske liv. Men i de nordslesvigske byer gjorde disse særlige forhold sig ikke gældende. Byer som Haderslev og Aabenraa var ret smaa og maa nærmest sammenlignes med fjordbyer som Vejle og Hor-

91) Nordisk Kultur II. (1938), 51-53 (Aksel E. Christensen), Handwörterbuch des Grenz- und Auslands-Deutschtums I (1936), $78 \mathrm{ff}$.

82) Aarhus gennem Tiderne I (1939), $241 \mathrm{f}$. (Jens Clausen), Viborg Købstads Historie I (1940), 39 (Hvidtfeldt). I en række tingsvidner fra det middelalderlige Aarhus nævnes en del af byens beboere $i$ det 15. aarhundrede. De bærer næsten alle danske navne (Hübertz: Aktstykker vedk. Staden og Stiftet Aarhus I (1845) $18 \mathrm{f}$., $24 \mathrm{f}$., $32 \mathrm{f}$., $96 \mathrm{f}$., $101 \mathrm{f}, \mathrm{f}_{\mathrm{f}}, 110 \mathrm{f}$, $120 \mathrm{f}$. I borgerskabsprotokollen fra Aarhus, der begynder 1471 (LA i Viborg), og hvoraf udtog er trykt i L. R. Hübertz anf. sted, $256 \mathrm{ff}$, findes der kun ganske faa borgere med tyske navne.

os) F. eks. Sach III, 215-319, Deutsches Archiv für Landes- und Volksforschung I (1937), 72 (Ludwig Andresen). 
sens, hvor der i middelalderen ikke synes at have været noget tysk befolkningselement ${ }^{94}$ ).

Som bevis paa byernes fortyskning fremføres ofte det nedertyske administrationssprog, som i det 15 . aarhundrede har været det almindelige $i$ alle de sønderjyske byer, og som gjorde det nødvendigt at oversætte byretterne til nedertysk. Forudsætningen herfor var de ydre statsretslige forhold, som medførte, at centraladministrationens, den øverste lokaladministrations og de højere retsmyndigheders skriftsprog blev nedertysk. Naar administrations- og retssprog i de nordlige byer ogsaa fortyskedes, kan det tænkes, at udviklingen i de sydlige byer $\mathrm{i}$ hertugdømmet - først og fremmest i Slesvig - har spillet en vis rolle.

Sønderjyllands historie gennem aarhundrederne viser, at folkesproget og det sprog, hvori embeds- og retsskrivelser udfærdigedes, ikke har nogen forbindelse med hinanden. De sønderjyske borgere og bønder talte og forstod ikke latin i det 13 . og 14. aarhundrede, og den nordslesvigske bondes kendskab til højtysk i det 18. og 19. aarhundrede var ikke væsentligt større. Men alligevel udfærdigedes næsten alle retsdokumenter og breve fra administrationen i de paagældende aarhundreder paa disse sprog. Iøvrigt er der grund til i denne forbindelse at fremhæve visse forhold, som uden tvivl har spillet en betydelig rolle og forklarer, hvorfor tingsvidnerne i det enkelte herred snart er paa dansk, snart paa tysk. Skrivekunsten var en evne, som væsentligst overklassen, gejstligheden og enkelte professionelle skrivere var i besiddelse af. I byerne er de skriftlige udfærdigelser formodentlig besørget af en særlig byskriver, mens herredsretternes breve i middelalderen til en vis grad ud-

94) Se de talrige Vejle-borgere, der nævnes 1468 (Repertoriet 2, r, II (1929), $104 \mathrm{ff}$.); en del Horsens-borgere forekommer $i$ et tingsvidne af 1492 (Repertoriet 2. r. IV (1932), 246 f.). De kendte borgmestre og raadmænd fra middelalderen (O. Fabricius: Horsens Kjøbstads Beskrivelse og Historie (1879), 188 ff., 220 f.) synes ogsaa næsten udelukkende at have været danske. 
færdigedes af modtagerne $\left.e^{05}\right)$. De tingsvidner, vi har bevaret fra middelalderen, angaar næsten udelukkende gejstligheden og adelen, altsaa kredse, hvor det tyske befolkningselement spillede en ikke ringe rolle. Et andet moment, som ogsaa kan have spillet en vis rolle, er, at brevene ofte kun kendes i afskrifter, som kan være oversættelser ${ }^{96}$ ). Iøvrigt maa man ikke sammenblande det retslige skriftsprog og det mundtlige forhandlingssprog. Saa længe de jævne bønder spillede en afgørende rolle paa tinge, maa sproget her have været dansk, da - som der foreligger utallige vidnesbyrd om - bønderne ikke kunde tysk ${ }^{97}$ ). Men efterhaanden som tyskuddannede herredsfogder og advokater kom til at spille en afgorende rolle, var det danske sprog paa tinge i stadig vigen. Derimod er forhanalinger angaaende kontrakter, skifter, gældsforhold m. m. forhold der hørte under den frivillige jurisdiktion - blevet ført paa dansk ${ }^{98}$ ). Det er saaledes klart, at vil man have kendskab til de befolkningsmæssige forhold i byerne i den senere del af middelalderen, er det ikke muligt at naa til et paalideligt resultat ved hjælp af skriftsproget. Da der ikke foreligger direkte udtalelser om sporgsmaalet, er der kun den mulighed tilbage at undersøge, om det foreliggende personnavnestof vil kunne fortælle noget am befolkningens nationale sammensætning. Det maa dog stærkt pointeres, at saadanne undersøgelser aldrig kan blive særlig paalidelige. De kan kun give et vist indtryk af forholdene ${ }^{99}$ ).

I Slesvig by gav det tyske domkapitel, de tyske bisper og det

95) For Hardsyssels vedkommende se: Peter Skautrup: Hardiske Maal II, (1942), 48 ff. Tilsvarende forhold kan paavises andre steder. For S $\phi$ nderjyllands vedkommende vil sp $\phi$ rgsmaalet først kunne afg $\phi-$ res endeligt ved hjælp af palæografiske unders $\emptyset$ gelser.

90) Historisk Tidsskrift 10. r., IV (1938), 437 (Johanne Skovgaard). Det vides, at en del tingsvidner fra det 16. aarhundrede vedrørende Løgumkloster er blevet oversat til tysk, jvnfr. ogsaa Allen I, 47.

97) Enkelte eksempler paa protest mod det tyske sprog som retssprog: Allen I, 228 f. Sdj. Aarb. 1943, 143-45, Jahrbücher für die Landeskunde VI, 176.

8) Jahrbücher für die Landeskunde VI.

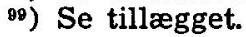


tyskorienterede hertughus særligt gode betingelser for en videre udvikling af det tyske element. Det er ikke muligt at følge udviklingen $i$ enkeltheder, men en fortegnelse fra 1406 over byens grundejere giver et holdepunkt for at bedømme forholdet mellem dansk og tysk-frisisk. Af de 200 navne $i$ listen er de 31 af usikker oprindelse, mens 44 af de resterende er danske, 125 tyske, d.v.s. $22 \%$ danske og 62,5 \% tyske ${ }^{100}$ ). Da der er tale om grundejere, altsaa den mere velstaaende del af befolkningen (flere af de nævnte er adelige), maa man regne med, at den danske del af befolkningen i virkeligheden har været betydelig større. Thi de danske tilvandrede, der kom fra de danske sogne mod nord og mod vest, har uden tvivl først og fremmest tilhørt byens underklasse, tyende og daglejere. Hvis man anslaar forholdet mellem dansk og tysk i Slesvig omkring 1400 til at være $1: 3$ er det maaske ikke helt forkert. Og forholdet synes at have været ret uforandret i de følgende aarhundreder ${ }^{101}$ ).

Fra Flensborg foreligger et temmeligt omfattende personnavnestof fra det 15. aarhundrede, der især findes $\mathrm{i}$ fortegnelser over medlemmer af gilderne og i den jordebog, der anlagdes i $1436^{102}$ ). En bearbejdelse af jordebogen er foretaget af $F$. Graef $^{109}$ ), dog delvis paa et fejlagtigt grundlag. Han har f. eks. anset navne paa -sen som tyske og navne paa -son som danske. En nyere og mere indgaaende undersøgelse - foretaget af Troels Fink ${ }^{104}$ ) - giver mere fast bund under fødderne. Det

100) Trykt Sach: Geschichte der Stadt Schleswig 173-176. Fortegnelsen er affattet paa latin, men er uden tvivl ført i pennen af en tysk skriver. Til gruppen usikre er henregnet navne, der baade forekommer paa dansk og tysk, herunder ogsaa oprindelig tyske navne, som længe $f \phi r$ 1400 har vundet borgerret i det danske sprog (f. eks. Claus og Henrik). Sach ansætter det danske element betydeligt lavere end her (højst 30 af 200). Aksel E. Christensen anslaar det til ca. $20 \%$ (Nordisk Kultur II (1938), 51-53.).

101) Sach: Geschichte der Stadt Schleswig 172.

102) Trykt Seidelin: Diplomatarium Flensborgense I (1860) og C. Nyrop: Danmarks Gilde- og Lavsskraaer fra Middelalderen I (18991900).

103) Die Heimat 1935, 329-37.

104) Festskrift til Knud Fabricius (1945), 13-29. 
fremgaar heraf, at af de $\mathrm{i}$ jordebogen forekommende navne var 64,2 \% dansk-frisiske, 24,3 tyske og 11,5\% „neutrale“. Ved hjælp af navnene i de flensborgske medlemslister og senere tilføjelser $i$ jordebogen er der gjort forsøg paa at faa et vist tidsperspektiv ind $\mathrm{i}$ undersøgelsen, og Fink har paa grundlag af dette materiale opstillet følgende tabel ${ }^{105}$ ).

Jordebogen 1436

Grundejere $1440-1500$

St. Gertrudsgilde 1428-45

Vor Frue Købmandsgilde 1420-41

" " $\quad " \quad 1441-70$

danskfrisisk $\%$

64,2

65,8

57,3

34,6

48,4

59,2

50,7 neutral

$\%$

11,5

11,8

8,7

11,8

10,2

9,5

17,6 tysk $\%$

24,3

22,4

34,0

53,6

41,4

31,3

31,7

Tabellerne viser tydeligt, at der i gilderne - og det gælder først og fremmest Vor Frue Købmandsgilde - har været et større tysk element end i den almindelige grundejende befolkning som helhed. Dette er i og for sig ikke saa underligt, da man netop indenfor købmandsstanden og de højere kredse, som gilderne repræsenterede, $i$ en handelsby som Flensborg maa vente et særligt stærkt tysk indslag. Mere overraskende er det, at tallene synes at vise, at den tyske tilvandring kulminerede $i$ 1430erne og nærmest var aftagende i resten af aarhundredet. Tyskerne i købmandsgildet blev færre og færre. Flensborg var ikke blevet fortysket, det danske befolkningselement var stadig det dominerende. Og det maa i denne forbindelse fremhæves, at tabellens tal først og fremmest omfatter købmænd og de med dem socialt ligestillede. De lavere klasser — især daglejere og tjenestefolk - har sikkert været næsten helt af dansk afstamning, enten fra byen eller det danske opland, maaske endda

205) Anf. sted. 24. I sin tabel har Fink to talrækker, den ene med en ret stor gruppe neutrale, som i den sidste række er fordelt paa de nationale grupper. $\mathrm{Da}$ denne fordeling maa anses for ret paalidelig, er disse tal benyttet her. 
fra Nørrejylland. Allerede 1588 fik Flensborg dansk gudstjeneste i Helligaandskirken af hensyn til tjenestefolk, haandværkere og søfolk ${ }^{10 \theta}$ ).

Fra de nordslesvigske byer foreligger der et meget begrænset navnestof. Fra Sønderborg er der saa at sige intet og fra Aabenraa næsten kun enkelte navne fra nogle regnskabsnotitser vedrørende skomagerlavet ca. $1496^{107}$ ). De fleste af de nævnte mænd har uden tvivl været skomagere. Her var 22 danske, 3 tyske og 5 usikre. Af 9 kvindenavne er de 8 sikkert danske, mens et maaske er tysk.

Fra Haderslev foreligger ikke nogen fortegnelse over beboerne, men en del spredte navne forekommer i tingsvidner og lignende. Af de 102 borgernavne, der kendes fra 1400 til $1500^{108}$ ), er 63 danske, 25 tyske og 14 ubestemmelige, eller $24,5 \%$ tyske, et ret betydeligt antal, naar man sammenligner med Flensborg. Forklaringen paa dette ejendommelige fænomen er dog sikkert den, at de personer, hvis navne er kendt, væsentligst tilhører overklassen - der findes et forholdsvis stort antal borgmestre og raadmænd mellem de nævnte - og det har især været indenfor denne, at tilvandringen har gjort sig gældende.

Fra Tønder kendes kun enkelte navne fra middelalderen. Omkring 1350 nævnes 19 personer ${ }^{109}$ ), hvoraf 9 med danske navne, 5 med tyske (tre af disse bærer slægtsnavnet Culige, men de to af disse har nordiske fornavne: Nis og Erik) og to med frisiske, mens resten er usikre. Af de spredte navne, der iøvrigt

106) Chr. Voigt: Flensburg. Ein Heimatbuch I (1929), 176, F. Graef: Geschichte der Heiligen Geistkirche und der dänischen Gemeinde in Flensburg (1926), 18. 20.

${ }^{107}$ ) Danske Magazin 6. r., VI (1932), 2, 10-13 til linie 9, de følgende navne synes at være fra et noget senere tidspunkt.

$\left.{ }^{108}\right)$ Th. O.. Achelis: Bürgerbuch der Stadt Hadersleben I (1940), 162, jvnfr. Sach III (1907), $287 \mathrm{ff}$.

${ }^{109}$ ) Zeitschrift XXXVIII (1908), 364-66 (Andresen). B. u. E. 158. Den af Andresen (B. u. E. 158, note 8) anførte datering (ca. 1300) kan ikke være rigtig. Navneformer som Jenssen og Nis viser, at optegnelsen maa være noget yngre, og palæografiske kriterier tyder, efter hvad arkivar Kroman har oplyst, paa, at affattelsestiden er ca. 1350. Jvnfr. ogsaa Tønder gennem Tiderne (1943-44), 466. 
kendes fra det 14. og 15. aarhundrede, er en del frisiske og enkelte tyske $\left.{ }^{110}\right)$. Det foreliggende materiale viser saaledes, at der er indvandret en del frisere til byen. Da der boede frisere lige udenfor bygrænsen, overrasker dette ikke. Ogsaa enkelte tyskere maa være kommet til byen, men det meget spredte materiale gør det ikke muligt at faa noget indtryk af, hvorledes forholdet mellem de forskellige nationaliteter har været. Først fra 1537 foreligger en fortegnelse over skatteydere i Tønder ${ }^{111}$ ), der omfatter 147 personer, hvoraf 24 kvinder. Af de 123 mænd har 76 -sen navne. 40 af disse var danske, 22 frisiske og 14 ubestemmelige. Af de resterende navne var 20 danske, 22 frisiske og 14 ubestemmelige. Ses der bort fra sidstnævnte kategori, var der altsaa 60 af navnene, der var danske, 27 frisiske og 7 tyske eller af det samlede antal henholdsvis 48,8, 21,9 og 5,7\%. Selvom man tager hensyn til opgørelsens usikkerhed og de andre mangler ved materialet, kan der ikke være tvivl om, at listen giver et vidnesbyrd om en overvejende dansk befolkning i Tønder paa reformationstiden. Som det paa forhaand maatte ventes, har der dog været et ret betydeligt frisisk indslag, mens den tyske indvandring var ret ringe.

Undersøgelsen af de sønderjyske købstæder i middelalderen har saaledes vist, at der i Slesvig findes et overvejende tysk befolkningselement, dog med et ikke helt ringe dansk islæt. I Flensborg og de nordslesvigske byer har befolkningen været overvejende dansk, selvom der alle steder kan paavises et tysk indslag. I Tønder findes et betydeligt antal frisere. De nordlige købstæder i Sønderjylland har uden tvivl rummet et større fremmedelement end kongerigske byer som Aarhus og Viborg, Vejle og Horsens. Men der har næppe været flere fremmede her end i Aalborg og i mange østdanske købstæder, ja, maaske har det tyske element endda været større i nogle af disse byer.

110) Andresen: anf. sted $158 \mathrm{f}$.

111) B. u. E. $160 \mathrm{ff}$. 
Stednavnene har vist, at den danske bebyggelse ikke naaede helt ned til Ejderen, og at der allerede $\mathrm{i}$ begyndelsen af det 13 . aarhundrede var en ikke ringe tysk befolkning i den sydlige del af Sønderjylland. Men holstenerne gjorde ikke holdt, da de naaede op til den danske bebyggelse. I de følgende aarhundreder skete der en tysk fremgang og kolonisation, som det dog ikke er muligt at følge $i$ enkeltheder. Men gennem undersøgelser af det personnavnestof, der findes i regnskaber, skattelister og jordebøger fra slutningen af middelalderen, kan man dog faa et begreb om, hvorledes forholdet mellem dansk og tysk var paa dette tidspunkt, og fastslaa, hvor grænserne mellem dansk og holstensk bebyggelse gik. Det maa imidlertid fremhæves, at der paa dette omraade er muligheder for nye forskningsresultater, og at ikke blot det historiske og filologiske materiale, men ogsaa det folkloristiske og etnologiske stof maa udnyttes fuldt ud ved saadanne undersøgelser. Kun derigennem vil det være muligt at naa frem til en præcis skildring af de senmiddelalderlige forhold og af den historiske udvikling, som har betinget den.

Personnavnestoffet fra S v a n s viser, at en stor del af bønderne i det 15. aarhundrede var af tysk afstamning. Men i alle sognene møder man dog stadig danske navne. Svans er endnu ikke paa dette tidspunkt fortysket, men er et udpræget nationalt blandingsomraade. Mest tysk var de sydligste sogne, Borreby og Vabs, mens der var en forholdsvis større dansk befolkning i Siseby, Riseby og Svans sogne. I en del af Kosel sogn havde .danskerne særlig forstaaet at hævde sig. Hundrede aar senere var det tyske befolkningselement blevet stærkere, men der var dog stadig en del bønder, der bar danske navne, -sen-navne eller slægtnavne af dansk rod. Det passer ogsaa godt med oplysninger hos Dankwerth om, at der paa hans tid blev talt baade dansk og saksisk i Svans. I Danske Atlas fortælles det, at der taltes angler-dansk i de landsbyer, der laa ved Slien, og endnu 
i 1865 mødte August Sach folk fra Svans sogn, der kunde huske, at der'es forældre havde kunnet tale dansk ${ }^{112}$ ).

Mens de dele af det sydligste Sønderjylland, der blev bebygget af tyskerne, synes at have været næsten ubeboede, da nybyggerne kom, var det anderledes med Svans og egnene vest derfor. Her var en gammel tilsyneladende rent dansk bebyggelse. Hvorledes er det da gaaet til, at byerne og gaardene her efterhaanden er blevet overtaget af folk, der talte tysk og bar tyske navne? Hvis der havde været tale om en udvikling som den, der skete i Angel i det 19. aarhundrede, hvor det ikke var indvandrere, der ændrede folkets nationalitet, men overgangen fra dansk til tysk skyldtes en bevidst viljeshandling fra befolkningens side, maatte man regne med, at de danske navne vilde have levet videre. Menneskene i ældre tid kunde lettere skifte sprog og sindelag end navneskik. Men de fleste af de navne paa bønder fra Svans, som vi møder i det 15. aarhundredes regnskaber og jordebøger, har mistet ethvert dansk præg, det er de samme navne, som vi kender fra egnen nord og syd for Rendsborg, fra de omraader, der altid har været tyske. Forklaringen herpaa synes kun at kunne være den, at der maa være kommet en del bonder til Svans sydfra. De har overtaget gaarde, der tidligere har været beboet af danske og har vel ogsaa nu og da taget ny udyrket jord under plov. Vi kan i dag ikke nærmere sige, hvorledes dette er sket, men det er nærliggende at tro, at den udvikling, der $\mathbf{i}$ det 15 . aarhundrede gjorde Svans til et udpræget nationalt blandingsomraade, hvor begge nationaliteter boede side om side, er blevet fremmet af den holstenske adel og gejstlighed, der ejede næsten hele Svans.

112) August Sach: Das Herzogthum Schleswig in seiner ethnographischen und nationalen Entwickelung III (1907), 40-77, Chr. Kock: Volks- und Landeskunde der Landschaft Schwansen (1912), 42-47. Den største del af personnavnestoffet er trykt i Quellensammlung der Gesellschaft f. schl.-holst. Geschichte VI (1904), 231 ff, 321-23, 353 -71 og i F. Falkenstjerne og Anna Hude: Sdj. Skatte- og Jordebøger fra Reformationstiden (1895-99), 411-14. 
Et ejendommeligt vidnesbyrd om den betydelige fortyskning i Svans allerede før 1500 er den mærkelige brug af tilnavnet Dene, dansker ${ }^{13}$ ). I mange byer findes der en eller flere mænd, der kaldes saadan. Det synes kun at betyde, at det at være dansk paa dette tidspunkt ikke har været almindeligt. Muligt er det, at tilnavnet kan være brugt om tilvandrere nordfra, vel især fra Angel, men selv i saa tilfælde siger det jo det samme.

Vest for Svans var den nogenlunde samlede tyske bebyggelse o. 1500 naaet op til linien Selknor, Kovirke, Dannevirke ${ }^{114}$ ). Der var dog stadig enkelte landsbyer, hvor der var en del af den danske befolkning tilbage. I Selk var der saaledes flere bønder med danske navne, saa det danske sprog maaske paa dette tidspunkt endnu har holdt sig her ${ }^{115}$ ). Og selv i det meget sydligt liggende St. Vittensø var der 3 af 16 bønder, der bar udpræget danske navne ${ }^{116}$ ). Maaske er der dog her nærmest tale om indvandrere nordfra.

Længere mod nord, i Arns herred, viser personnavnene, at der er tale om et nationalt blandingsomraade. I byerne Hollingsted, Elingsted, Store og Lille Dannevirke og Husby er de tyske navne $\mathrm{i}$ absolut flertal, idet de udgør en $60-80 \%$ af det samlede tal. I Skovby havde endnu i 1509 et flertal af bønderne danske personnavne, 9 af 14, og i 1542 er der omtrent ligevægt mellem de to nationaliteter. Senere vandt danskheden dog atter frem, og efter Ulrik Petersens udsagn taltes her endnu i 1700aarene dansk ${ }^{117}$ ). I Sylvested var antallet af bønder med danske og med tyske navne omtrent lige stort. Vi er nu naaet op til den tyske bebyggelses nordligste grænse. Her gjorde det saksi-

$\left.{ }^{113}\right)$ Se f. eks. Quellensammlung der Gesellschaft f. schl.-holst. Geschichte VI (1904), $355 \mathrm{f}$., $359 \mathrm{f}$.

114) Sdj. Aarbøger 1893, 268 f. (P. Lauridsen).

115) Sach: anf. værk III, $132 \mathrm{f}, 136$ f. Naar Ulrik Petersen senere fortæller, at der for ikke saa lang tid siden endnu hørtes dansk paa vejen fra Slesvig til Rendsborg, kan det efter Sachs mening kun være 1 Overselk.

116) Sønderjydske Skatte- og Jordebøger 349.

11i) Sach: anf. værk III, 184 ff. 
ske fremstød holdt, og nordfor, i byer som Lyrskov, Arenholt, Jydbæk og Treja, møder vi i begyndelsen af 1500-aarene næsten kun bønder med danske navne $\left.{ }^{118}\right)$. Det skulde vare næsten tre aarhundreder, inden det tyske fremstad atter blev sat ind, men da blev det ikke baaret frem af en kolonisationsbølge, men at en tysk kultur- og sprogpropaganda, hvis baggrund var hertugdømmets særegne administrative forhold. Op til omkring 1800 var og blev landevejen mellem Husum og Slesvig den samlede danske bebyggelses sydgrænse.

I den vestlige del af Slesvig var de nationale forhold mere indviklede. Navnestoffet i Ostenfeld sogn 1542 var overvejende dansk om end med et vist tysk og frisisk islæt. Naar man senere i Hollingsted betegnede sognet som „danskersiden“, tyder det ogsaa paa en forholdsvis sen germanisering ${ }^{119}$ ). Svesing var i 1500-aarene, som det var at vente, næsten rent dansk ${ }^{120}$ ). I et kirkevidne fra 1512 omtales Rantum, Mildsted og Rödemis bymarkers grænser som grænsen mod "friserne, som bor i syd overfor dem". Da det altsaa ikke kan være frisere, der boede $\mathbf{i}$ de tre byer, bliver spørgsmaalet, om det var danskere eller tyskere. Personnavnene tyder paa, at det danske befolkningselement i Rödemis og Rantrum var i overvægt, mens der var omtrent ligemange danske og frisiske navne i Mildsted ${ }^{121}$ ). I modstrid hermed staar stednavnestoffet, som synes at vise, at Mildsted og Rantrum er af dansk, Rödemis af frisisk oprindelse, men at de tre byer i 1400-aarene har været tysktalende, i hvert fald har haft tysk omgangssprog ${ }^{122}$ ). Denne antagelse, der kun er en videnskabelig hypotese, kan dog være forkert. I hvert fald er der ikke tvivl om, at personnavnene $i$ disse sogne enten er danske eller frisiske, under ingen omstændigheder nedertyske ${ }^{123}$ ).

118) Sach anf. værk III, $185 \mathrm{ff}$, Sdj. Aarb $\phi$ ger 1893, $269 \mathrm{ff}$.

119) Sdj. Aarb. 1893, 285-88, 1944, 7, Sach: anf. værk 327 ff.

120) Sach: anf. værk III, $326 \mathrm{f}$.

121) Sdj. Aarb. 1893, 283 ff.

122) Sdj. Aarb. 1944, 4 ff.

12s) Se f. eks. Sønderj. Skatte- og Jordebøger s. 315 f. 
Der er en saa afgjort forskel mellem navnene her og i de fortyskede sogne længere mod vest, og der skal derfor meget tvingende grunde til at formode, at der omkring 1500 har boet en plattysk talende befolkning her.

Svabsted længere mod syd, ved Trenen, var formodentlig oprindelig dansk, men var i 1400-aarene blevet fortysket. Personnavnene viser dog ogsaa et betydeligt frisisk islæt, ligesom der forekommer enkelte danske navne ${ }^{124}$ ).

I det vestslesvigske kystomraade fra Husum til Tønder var det ikke tyskere og danskere, men frisere og danskere, der mødtes. Allerede $i$ den ældre middelalder var friserne fra marsken ikke blot naaet frem til geestranden, men var endda kommet ind paa geesten ${ }^{125}$ ). I middelalderens senere aarhundreder blev fremrykningen fortsat, og der opstod her et blandingsbælte, hvor begge nationaliteter boede side om side. Mens personnavnestoffet i de sydligere grænseomraader, hvor tysk og dansk mødtes, er af en saadan karakter, at der ikke er større vanskeligheder ved at skelne mellem tyske og danske navne, er det betydeligt sværere at afgøre, om der er tale om danske eller frisiske navne, dels fordi baade danskere og frisere har brugt patronymier, dels - og især - fordi en ret betydelig del af navnestoffet er fælles. De frisiske slægtsnavne dannes dog i modsætning til de danske -sen navne ved et efterhængt -s, -ens, -en og -ing. Men i det middelalderlige skriftlige kildemateriale med den stærke anvendelse af forkortelser kan forskellen mellem -sen, -s, -ens, -en let udviskes. Men trods disse vanskeligheder kan der dog ikke være tvivl om, at de mange særprægede frisiske fornavne gor det muligt at danne sig et ret paalideligt indtryk af forholdet mellem de to nationaliteter ${ }^{126}$ ).

124) Sdj. Aarb. 1944, $7 \mathrm{f}$, Sach: anf. værk $317 \mathrm{f}$.

125) Se side $168 \mathrm{ff}$.

126) Peter Jørgensen har i værket: Ubber die Herkunft der Nordfriesen s. 133 afvist muligheden af at bruge personnavnene som vidnesbyrd om etnografiske grænser. Hans grunde herfor er dog langtfra overbevisende. Han mener bl. a., at personnavnene i høj grad har 
O. 1500 synes sognene Skobøl, Hatsted, Breklum, Bordelum, Bargum, Stedestand, Lindholm, Nibøl, Nykirke og Aventoft at have været de østligste sogne, hvori der var en altovervejende frisisk bebyggelse, mens sognene Svesing, Fjolde, Hjoldelund, Nr. Haksted, den østlige del af Læk s., Karlum s., den østlige del af Brarup samt Humtrup s. udgjorde vestgrænsen for den overvejende danske befolkning. Herimellem fandtes en del byer og egne, som hverken var frisiske eller danske, men et udpræget blandingsomraade. Det var Trelstorp s., Enge s., den vestlige del af Læk s., Klægsbøl s., den vestlige del af Brarup s. samt Humtrup s. Hertil bør maaske ogsaa henregnes den sydligste del af Breklum sogn, hvor byerne Almtorp og Valsbøl viser et vist dansk islæt, selvom flertallet af navnene afgjort er frisiske ${ }^{127}$ ).

Denne undersøgelse af forholdet mellem dansk-tysk-frisisk i de sønderjyske landsogne ved middelalderens slutning har kun omfattet den sydligste del af Sydslesvig. Landsbyerne nordfor de behandlede omraader frembyder i disse aarhundreder ingen nationale problemer. Et blik paa de hundreder af navne, der i regnskaber og jordebøger er bevaret fra middelalderens sidste aartier, viser, at det var danske bønder, der levede her.

været laanegods. En almindelig betragtning af sønderjysk navneskik, efter at de kristne navne havde sejret, tyder ikke paa, at denne paastand er rigtig. Naar der rundt om i Nordslesvig i nyere tid findes frisiske navne, kan de i mange tilfælde føres tilbage til frisiske indvandrere. I tidens $1 \phi b$ kan de fremmede navne gennem »arv « spredes ret vidt om. En saadan spredning kan selvfølgelig tilsløre de etnografiske forhold, men kan ikke karakteriseres som laan.

127) Oversigten er dels udarbejdet paa grundlag af oplysningerne i P. Lauridsens afhandling: Om Nordfrisernes Indvandring i S $\varnothing$ nderjylland (Hist. Tidsskr. 6 r. IV, 318-367), Sach: anf. værk II, 280-336 og det omfattende personnavnestof, der er trykt i Falkenstjerne og Hude: Sønderjydske Skatte- og Jordebøger. Det maa iøvrigt fremhæves, at disse grænseangivelser kun kan være omtrentlige. Det vil ikke væere muligt at naa frem til større videnskabelige sikkerhed, før der er foretaget meget indgaaende unders $\varnothing$ gelser over, hvilke personnavne, der ved middelalderens slutning var i brug baade hos frisere og hos danskere. Sachs og Lauritsens arbejder er værdifulde, men deres forskningsmaade er dog for upræcis og umetodisk til at give helt sikre resultater. 
Oldtid og middelalder har haft afgørende og skæbnesvanger betydning for Sønderjyllands historie. For dansk nationalitet blev udviklingen i de sidste aarhundreder sørgelig og trist. Baade mod syd og mod vest var dansk i vigen overfor tysk og frisisk. Og politisk var det tyskerne, der havde magten. Det kunde se ud, som om den dag ikke skulde være saa fjern, da danskheden maaske helt forsvandt, i hvert fald fra Sydslesvig. Det kom dog til at gaa anderledes.

Joh an Hvidtfeld t.

\section{Tillæg.}

I det foregaaende er der foretaget en del undersøgelser paa grundlag af personnavnestoffet i Sønderjylland, og der vil derfor være grund til at gøre nogle principielle bemærkninger om værdien af saadanne undersøgelser og om sønderjysk navneskik. En statistik, bygget paa en national klassifikation af navnene, kan aldrig faa samme værdi som en indvandringsstatistik. Slægter med tyske navne kan have levet i Sønderjylland gennem mange generationer og maaske forlængst være blevet danificeret, eller indgifte i danske slægter kan have medført, at der er mere dansk end tysk blod i slægtens aarer. Der er mange sønderjyske familier i dag, som bærer fremmede navne og er saa danske som nogen. Saaledes har grænselandets vilkaar været gennem tiderne. Linierne kan ikke altid trækkes skarpt op. Men disse forhold medfører en stærk skævhed, som maa tages i betragtning ved bedømmelsen af statistikkens tal, som let vil komme til at give et for stærkt indtryk af fremmed befolkningsindslag. Man behover bare at forestille sig, at man skulde foretage en vurdering af de nationale forhold $\mathbf{i}$ det 20 . aarhundredes Danmark paa grundlag af en navnestatistik over den danske befolkning. Fremhæves maa det ogsaa, at de fremmedartede og faste slægtsnavne - trods befolkningens konservatisme - havde en tendens til at dominere. En senere erfaring 
viser, at saadanne navne i mange tilfælde var arvelige paa spindesiden. En statistik, udarbejdet paa grundlag af personnavnene bliver hverken en indvandringsstatistik, en sprogeller en sindelagsstatistik. Den er kun et fingerpeg, den kan give et indtryk af hovedlinierne i udviklingen, ikke mere.

Iøvrigt er materialet ogsaa behæftet med andre mangler. Det er saa at sige altid ufuldstændigt, idet det ikke omfatter hele befolkningen, og navneformerne er os kun bekendt gennem et mellemled, skriveren. Da disse saa at sige uden undtagelse har haft (neder)tysk skriftsprog, maa man regne med, at sprogformerne næsten altid er tyske. Dette gælder baade selve navnene og erhvervsbetegnelserne, der ofte erstatter efternavnene, og man kan derfor ikke som f. eks. Sach (III, 228) og Graef (Die Heimat 1935, 334) har gjort, slutte til tysk afstamning fra en tysk erhvervsbetegnelse som Schröder eller Kremer. Hvis en mand med en saadan betegnelse bærer et dansk fornavn, maa han betragtes som dansk.

Spørgsmaalet om patronymika frembyder ogsaa en del vanskeligheder. Det har i de senere aar været underkastet en del diskussion, om denne navneform væsentligst var begrænset til det danske (og frisiske) kulturomraade eller om den ogsaa brugtes i Holsten og Tyskland. Ludwig Andresen har i Von Volkstum und Namengebung im Schleswigschen (1937), 6 ff., jvnfr. Bürger- und Einwohnerbuch der Stadt Tondern (1937), fremdraget en del eksempler paa patronymika udenfor Slesvig, mens Troels Fink i Festskrift til Knud Fabricius (1945), 26 ff. gennem en undersøgelse af et toldregnskab fra Gottorp 1484-85 har vist, at -sen-navnene er overvejende hos personer fra kongerigske byer og Flensborg, men forsvindende hos personer fra tyske byer (kun 4,1 \%). Denne undersøgelses rigtighed bekræftes ogsaa af de resultater, som A. Reimpell er naaet til gennem en analyse af navnestoffet i Lübeck 1250-1350 (Fink: anf. sted, 26.). Angaaende spergsmaalet kan iøvrigt hen- 
vises til Die Heimat 1911, 135-139 (Wahl) og Jahrbuch des Heimatbundes Nordfriesland 1937, 138-49 (P. Martensen). Sidstnævnte hævder, at brugen af patronymika i Sønderjylland er af dansk oprindelse og strækker sig ned til den gamle folkegrænse. Der er altsaa heller ikke enighed indenfor de tyske forskeres kreds.

Der kan efter de nu foreliggende undersøgelser næppe være tvivl om, at brugen af patronymika har været meget sjælden i de tyske omraader. Men helt se bort fra muligheden af, at bærere af -sen-navnene er indvandret sydfra, kan man dog ikke. Hertil kommer, som paapeget af Ludwig Andresen, at tyske slægter i løbet af en generation eller to kan miste deres slægtsnavn og i stedet bruge patronymika (B. - u. E. 163). Erfaringen viser dog, at der som nævnt - ikke mindst i byerne - var en stærk forkærlighed for faste, særprægede slægtsnavne. Det er klart, at man i betragtning af disse forhold ikke uden videre kan betragte alle bærere af patronymika som folk af rent dansk afstamning; man maa i hvert enkelt tilfælde foretage en undersøgelse af navnenes karakter. Hvis baade forog efternavn er af udpræget tysk oprindelse - noget der ret sjældent forekommer - maa vedkommende betragtes som tysk.

Afgørelsen af, om en person skal betragtes som værende af dansk eller tysk afstamning, er i det foregaaende sket paa grundlag af en vurdering af baade for- og efternavn. Er der væsentlig tvivl om navnets nationale karakter, enten paa grund af væsentlig uoverensstemmelse mellem for- og efternavn, eller fordi navnene baade kan være dansk og tysk, er vedkommende henregnet til "ubestemmelige“. Selv om der ved vurderingen gaaes frem med den største forsigtighed og skønsomhed, vil der selvfølgelig altid blive plads for en vis usikkerhed. Erfaringen viser dog, at vanskeligheden med at klassificere et navn ikke er saa stor, som man paa forhaand skulde tænke sig 
Hvor der intet andet er bemærket, er frisiske navne henregnet til de tyske. Ved afgørelsen af, om et navn er dansk, tysk eller frisisk har oplysningerne i Danmarks gamle Personnavne I (1936 ff) og Johs. Kok: Det gamle Folkesprog i Sønderjylland II (1867) været normgivende. 